NBER WORKING PAPER SERIES

\title{
HOW DOES INFORMATION TECHNOLOGY REALLY AFFECT PRODUCTIVITY? PLANT-LEVEL COMPARISONS OF PRODUCT INNOVATION, PROCESS IMPROVEMENT AND WORKER SKILLS
}

\author{
Ann P. Bartel \\ Casey Ichniowski \\ Kathryn L. Shaw \\ Working Paper 11773 \\ http://www.nber.org/papers/w11773 \\ NATIONAL BUREAU OF ECONOMIC RESEARCH \\ 1050 Massachusetts Avenue \\ Cambridge, MA 02138 \\ November 2005
}

\begin{abstract}
The authors gratefully acknowledge the generous support of a grant from the Russell Sage and Rockefeller Foundations and outstanding research assistance from Ricardo Correa, Radha Iyengar and Yoonsoo Lee. We thank the seminar participants at the Harvard-MIT Organizational Economics Workshop, Princeton University, Stanford University, UC Berkeley, the NBER Labor Studies/Personnel Summer Institute, and the NBER Organizational Economics Conference, the 2004 AEA meetings and the 2004 Society of Labor Economics. We appreciate the detailed comments of David Autor, George Baker, Thomas Hubbard, Lawrence Katz, Edward Lazear, and Erica Plambeck. Finally, the authors also thank the industry participants who generously provided their time and insights in the course of conducting this study, and Scott MacIntyre for his careful review of the technological elements of the paper. The views expressed herein are those of the author(s) and do not necessarily reflect the views of the National Bureau of Economic Research.
\end{abstract}

(C2005 by Ann P. Bartel, Casey Ichniowski, and Kathryn L. Shaw. All rights reserved. Short sections of text, not to exceed two paragraphs, may be quoted without explicit permission provided that full credit, including (C) notice, is given to the source. 
How Does Information Technology Really Affect Productivity? Plant-Level Comparisons of Product Innovation, Process Improvement and Worker Skills

Ann P. Bartel, Casey Ichniowski, and Kathryn L. Shaw

NBER Working Paper No. 11773

November 2005

JEL No. O33, J24, L25

\begin{abstract}
This study presents new empirical evidence on the relationship between investments in new computer-based information technology (IT) and productivity by investigating several plant-level mechanisms through which IT could promote productivity growth. We have assembled a data set on plants with a common production technology in a narrowly defined industry - valve manufacturing - to study the effects of new IT on product innovation, production process improvements, employee skills and work practices. The homogeneity of the plants' production processes within this narrowly defined industry together with the estimation of longitudinal models eliminate many sources of unmeasured heterogeneity that could confound productivity comparisons in more aggregate data and in broader samples. The three main results of this study highlight how the adoption of new IT-enhanced machinery involves much more than just the installation of new equipment on the factory floor. We find that adoption of new IT-enhanced equipment (1)alters business strategies, moving valve manufacturers away from commodity production based on long production runs to customized production in smaller batches; (2)improves the efficiency of all stages of the production process with reductions in setup times supporting the change in business strategy and (3)increases the skill requirements of workers while promoting the adoption of new human resource practices.

$\begin{array}{lll}\text { Ann P. Bartel } & \text { Casey Ichniowski } & \text { Kathryn L. Shaw } \\ \text { Graduate School of Business } & \text { Graduate School of Business } & \text { GSB, Littlefield 339 } \\ \text { 3022 Broadway, 816 Uris Hall } & \text { 3022 Broadway, 713 Uris Hall } & \text { Stanford University } \\ \text { Columbia University } & \text { Columbia University } & \text { Stanford, CA 94305-5015 } \\ \text { New York, NY 10027 } & \text { New York, NY 10027 } & \text { and NBER } \\ \text { and NBER } & \text { and NBER } & \text { kathryns@gsb.stanford.edu } \\ \text { apb2@ columbia.edu } & \text { bei1@ columbia.edu } & \end{array}$
\end{abstract}




\section{Introduction}

Rapidly advancing capabilities of computing equipment have spawned hosts of new information technologies that have undoubtedly reshaped the economy. Many analysts argue that business investments in new information technologies (IT) were responsible for accelerated productivity growth of the 1990's. This study presents new empirical evidence on the relationship between investments in new computer-based IT and productivity by investigating several plant-level mechanisms through which IT could promote productivity growth. We investigate whether IT serves as a "general purpose technology" (Bresnahan and Trajtenberg, 1995 , p. 84) that makes it easier to invent and produce new products, thereby contributing to increases in productivity growth. ${ }^{1}$ We also study whether plants that make new IT investments also make complementary investments in a more skilled workforce or in new types of work organization that themselves can contribute to higher productivity. ${ }^{2}$ While several studies indicate that the timing of IT investments matches the timing of productivity changes for the economy and that industries that made larger investments in computer technologies experienced larger productivity gains, ${ }^{3}$ evidence which documents whether plants that adopt new IT are in fact the same ones that increase the customization and reliability of their products and the speed and efficiency of their operations would provide a fuller understanding of what lies behind the macro-level trends.

To study the effects of new IT on product innovation, production process improvements, employee skills and work organization, we have assembled a data set on plants with a common production technology in a narrowly defined industry - valve manufacturing. These data allow us to conduct particularly convincing empirical tests of the effects of IT. The homogeneity of the plants' production processes within this narrowly defined industry together with the estimation of longitudinal models eliminate many sources of unmeasured heterogeneity that confound

\footnotetext{
${ }^{1}$ For evidence on the micro-level empirical relationship between IT and productivity, see Brynjolfsson and Hitt (2003). Milgrom and Roberts (1990) provide a theoretical framework that explains how IT promotes the movement towards customization based on the design of unique products for each customer while Da Silveira, Borenstein and Fogliatto (2001) discuss the effects of IT on mass customization. Athey and Stern (2002) and Hubbard (2003) study IT-related improvements in production processes.

${ }^{2}$ Examples from the extensive literature on the effects of computer technologies on worker skills are Autor, Katz and Kearny (2005), Autor, Katz and Krueger (1998), Autor, Levy and Murnane (2003), Dunne and Schmitz (1995), and Doms, Dunne and Troske (1997). Bresnahan, Brynjolfsson, and Hitt, (2002), Black and Lynch (2001), Bresnahan and Greenstein (1996), and Mendelson (2000) present evidence on the link between computer-based IT and new work practices.

${ }^{3}$ See Jorgenson, Ho and Stiroh (2003) and Oliner and Sichel (2000).
} 
productivity comparisons in more aggregated data and in broader samples. Also, our industryspecific measures of IT are more detailed than expenditures on computing equipment or employees' use of computers, and instead identify specific types of IT-enhanced capital equipment used in valve manufacturing. These measures of IT vary across stages of production within a plant, permitting the estimation of within-plant stage-specific models of the effects of IT that can further rule out interpretations that any estimated productivity improvements are due to unmeasured plant-specific factors.

The empirical analysis reveals three main results that highlight how the adoption of new IT-enhanced machinery involves much more than just the installation of new equipment on the factory floor. First, adopting new IT-enhanced equipment alters business strategies of valve makers, moving them away from commodity production based on long production runs to customized production in smaller batches. Second, new IT investments improve the efficiency of all stages of the production process by reducing setup times, run times and inspection times. The reductions in setup times are theoretically important because they make it less costly to switch production from one product to another, and support the change in business strategy to more customized production in smaller batches. Third, the adoption of new computer-based IT also increases the skill requirements of workers, notably technical skills, while also promoting the adoption of new human resource practices.

While an obvious limitation of such a plant-level study from a single industry is its generalizability, there are important reasons to believe that the positive effects of IT investments on process efficiency and product customization apply more broadly throughout the economy. Increasing customization of products and services is common across many areas of the economy, and this change often appears to be accompanied by the adoption of new computer-aided IT. The patterns that we document here in valve manufacturing are mirrored by examples from research on many non-manufacturing industries. In call centers, new IT reduces preparation times between calls. In hospital emergency rooms, new technologies speed the time between a patient coming into the hospital and treatment by the proper experts (Gabor, 2004). And in concert events, IT allows for customization of ticket packages based on current demand conditions and ticket supply. ${ }^{4}$ Just as new IT promotes more customized production by reducing setup times for

\footnotetext{
${ }^{4}$ Michael Rapino, CEO of Clear Channel reported that his concert production business "has become a lot more about customization. It used to be fairly generic: three ticket prices and maybe a T-shirt and a hat. There's an
} 
valve makers, faster information processing technologies foster customization in other industries by reducing the time it takes to prepare a customized telephone script for the next customer, a customized evaluation and treatment of a new patient, or a customized ticket package for the next concert fan. ${ }^{5}$ While the adoption of new IT appears to enable greater customization of products and services in many industries, documenting these productivity-enhancing effects of new computer-based technologies requires the kind of detailed data we have collected on product varieties, operating efficiencies, and organizational practices from plants in a single industry.

Sections II and III describe the valve-making production process, present case study regression results from one plant, and develop a theoretical model of the decision to invest in new IT equipment and its effects on productivity. Sections IV through VIII describe our survey data and present econometric evidence on the relationship of new IT investments to process efficiency and product innovation, to exit and entry of different types of plants in the industry, and to worker skills and employment practices. Section IX concludes.

\section{The Valve-Making Production Process}

A detailed investigation of how IT investments affect productivity, skill demand and work organization requires rich establishment-level data. We ground this study in the context of a single narrowly defined industry, valve manufacturing, to make the measures and models of IT investment and productivity growth more convincing. This section reports on observations from visits to five plants, including one case study with detailed performance data which inform the study's data collection efforts, theoretical model, and empirical tests. The descriptions of products and processes in this section are valuable in interpreting the model and variables that underlie later empirical results.

\section{The Production Process in Valve Manufacturing}

A valve is a metal device attached to pipes to regulate the flow of liquids or gases. Valves can be a commodity product, such as valves that control the flow of air in standard air conditioners, or a highly customized product, such as valves built to order for a new chemical plant or a submarine. To picture a few varieties of valves, see Figure 1. The production process

incredible amount of pressure to innovate and invest in (research and development) and the infrastructure." USA Today, September 27, 2005, p. 2B.

${ }^{5}$ For evidence on how the Internet increases product variety, see Brynjolfsson, Smith and Yu (2003). 
in valve making is a machining operation. ${ }^{6}$ A valve is made by taking a section of raw material and completing several processes on one or more machines, such as machining threads at each end for screwing the valve to pipes, boring holes at different locations to attach control devices, and manufacturing and assembling various devices that control the flow.

\section{$\underline{\text { IT Advances in Valve-Making Machinery and "Process Innovation" }}$}

Forty years ago, valve manufacturing was performed conventionally by highly skilled machinists using manual machine tools. Today, much of valve manufacturing is highly automated with new computer-based IT features embedded directly in the production equipment. The central piece of equipment in the valve manufacturing process is a computer numerically controlled $(C N C)$ machine that fixes the raw material on the pallet of the machine and automatically machines the valve component using commands entered as code into the machine's operating software via the machine's controller. ${ }^{7} \mathrm{CNC}$ machines are now in widespread use in the industry, as our survey data below will show. While the 'computerization' in the CNC label began when the CNC machines were introduced in the 1970s, CNC machines at that time were controlled using punched paper tapes that were programmed off-line by computer programmers and fed to the machines via a tape reader. Today, after substantial advances in information processing technologies, the computing power is embedded directly into new CNC machine controllers. (See Figures 2 and 3 for pictures of $\mathrm{CNC}$ machines in use in the late 1980s and today.) Because the computing power is now embedded in the capital, only field research of specific machines under the guidance of experts in these technologies can identify the IT features of new CNC machines and how these features change and improve valve production. We offer several examples of the new IT features of CNC machines and their effects on the production process.

The key IT element of the CNC machine is in the CNC controller. The controller box tells the machine exactly what to do - where to cut, how deep, the angle of the cut, the diameter, how many times to cut, how to move the steel to re-cut, and so on. After 1998, CNCs were equipped with fusion control - a more "conversational" technology that is much easier for operators to understand and program. Simplifying the process of programming the many tasks of

\footnotetext{
${ }^{6}$ Other processes are welding and assembly of multiple machined parts and final packaging and shipping.

${ }^{7} \mathrm{CNC}$ machines were predated by numerically controlled (NC) machines in which fixed computer programs for a given run, originally input on tape, controlled the action of machines during that run. Manual, NC, and CNC machines of different vintages all still exist in the industry, but sophisticated CNC are now dominant.
} 
machining and adding fixtures leads directly to dramatic reductions in machine setup times - the time spent programming the CNC to produce the next model. Fusion control was standard in new CNC machines by $2003 .^{8}$

New advances in computerization of the CNC have also reduced the run-time - the time it takes machines to perform the machining processes, though plant engineers reported that reductions in run times are limited by the actual speed that any equipment can machine a specific type of material. New CNC controllers have improved the 'axis capabilities' of these machines. Newer 5-axis CNC millers can machine a valve component on five different angles or axes in one "fixturing" operation. An older 3-axis CNC machine tool would require the valve to be manually repositioned within the machine tool to machine on a fourth or fifth axis. Run times are shorter on CNC machines with greater axis capabilities when they eliminate the need for any such repositioning. There have also been advances in the IT component of CNC controllers that allow the controller to use its computing resources more efficiently. An example is curve interpolation, which allows CNC machine tools to create smooth curves on a valve component instead of having to approximate curves using a large number of linear cuts. This reduces the software size, which decreases the amount of memory needed to perform a given task. Smaller programs are also easier to edit, troubleshoot and optimize thus reducing setup and run-times.

Overall, managers report that increases in computing power improved the capabilities of CNC machines considerably. Not only can operators program a modern CNC machine more easily through much simpler software interfaces, but each CNC machine can now perform a much wider variety of tasks on a piece of the raw material. Plant managers and engineers noted that a direct result of these technological improvements in the capabilities of CNC machines is a reduction in the number of $C N C$ machines needed to produce a given product. For example, at one plant, producing a typical product required seven machines in 1980; by 2002 that same product is now made with only two CNC machines that are more sophisticated.

A second technological advance in valve making is the use of flexible manufacturing systems $(F M S)$ that coordinate machining operations across several different CNC machines simultaneously. FMS involves the installation of a separate computer that is connected to the controls on several CNC machines. This computer coordinates machining tasks across these different CNC machines and directly reduces setup-time. FMS also helps optimize decisions

\footnotetext{
${ }^{8}$ Interview with chief operating officer of one company during plant visit.
} 
about which parts of a valve should be produced on which CNC machine to reduce runtime. FMS can also automatically monitor which cutting tools the CNCs are using and reduces the number of tool changes that are required as the controller allocates jobs across different CNC machines. This also reduces run times. ${ }^{9}$

Finally, our interviews identified IT advances that reduce the inspection time in the quality control process. Each dimension of a complicated valve often must be produced to an accuracy of 1/1000 of an inch, so inspection is a critical part of the production process. For many years, employees did time-consuming inspections with manual measuring devices. Over the last several years, automated inspection sensor machines have been introduced which use a touch-probe technology. Operators run programmed sensors to measure each feature of the valve component, creating a three-dimensional picture of the valve that is automatically compared to computerized models of the desired end product's specifications. ${ }^{10}$

Another technology that is becoming more common in valve making plants is threedimensional computer-aided-design $(3 D-C A D)$. This is a constantly advancing IT method for turning customers' valve specifications into a specific design, thereby reducing the time that elapses from order placement to design presentation to the customer.

$\underline{\text { IT Advances in Valve Making Machinery and "Product Innovation" }}$

Managers we interviewed consistently underscored two key operational imperatives for remaining competitive in this industry. First, reductions in setup, run, and inspection times are critical since many plants can produce a given customer's order. Filling the order quickly and efficiently is therefore important. According to the experience of plant managers we interviewed, the IT advances described in this section make plants more competitive by improving the efficiency of the production process. But managers also emphasized that product innovation and customization was a second critical area of competition in the industry. Production of more standardized commercial valves is moving abroad to low wage countries, so U.S. valve-makers are relying on a strategy of increasing their capabilities of customizing valves to meet specific customers' needs. Therefore, many U.S. valve makers are increasing the number of customized

\footnotetext{
${ }^{9}$ Plants that implement FMS are also likely to put higher-quality controllers on their CNC machines, which reduces setup time and runtime. In the setup and run time regressions below, this will show up as a return to FMS.

${ }^{10}$ The most recent inspection technology, which became available in 2004, enables the inspection to be done without any human contact; the inspection machine surrounds the valve and operates the probe to measure its features and check them against required specifications.
} 
products they produce and are relying less on selling the standard set of valve products listed in their catalogs, as their overall catalog sales have declined.

The IT advances described in this section also play a critical role in the move toward product customization. As more sophisticated controllers make changeovers between product runs faster and therefore less costly, plants will be able to start producing a greater number of different products in smaller manufacturing lots. New controllers in CNC machines that produce a valve component more accurately and with a greater number of features also allow plants to produce more product varieties at a reduced cost.

Econometric Case Study Evidence: the Effects of IT on Process Efficiency

One of the five plants where we conducted interviews and inspections of machining operations worked closely with us and provided their own proprietary data. These data illustrate several important points about how to measure operating efficiency in this industry. First, product heterogeneity is important. This plant provided data on the 331 distinct valve products made during 1999-2003. ${ }^{11}$ Second, plants track operations in distinct stages of valve production. Data for this plant are available on setup-time and run-time but not inspection time. For this plant, the largest component of production times was in setup. Managers indicated their plant was not unusual in this respect.

These longitudinal, product-specific data provide the opportunity to examine productivity gains over time as the plant introduced new machines aimed at lowering setup and run times. The plant did not introduce FMS technology during the period. The plant has continually purchased new CNC machines to raise the quality of the machines in use. The plant's machine operators explained that the best measure of CNC quality that we could use from the available data was the number of machines used to produce a given product. When the plant introduces a higher quality $\mathrm{CNC}$ machine into the production process for a given valve, it routinely replaces more than one $\mathrm{CNC}$ machine of an older vintage. Therefore, we define the variable "CNC Quality" as the number of CNC machines used to produce the product - a reduction in the

\footnotetext{
${ }^{11}$ The products selected for this analysis are those that were produced more than once with exactly the same detailed product code. Some data on these valves extend back from 2003 to 1978 , but $75 \%$ of the data is for 1999-2003, and all data are only for those valves in production between 1999 and 2003. This data set contains 790 observations for 331 products, or about 2.5 years of data for each product. The data are product-specific on scheduled setup-time and runtime for each machine on which the product will be run. Because the data pertain to scheduled and not actual production times, the time-series variation in these data are not a result of production line failures or of temporal shocks in demand.
} 
number of machines in the fixed effects regressions is an increase in CNC quality. ${ }^{12}$ The detailed records made available by this plant report the number of $\mathrm{CNC}$ machines used in production for each product.

Using this plant's time series data on 331 products, we estimate regressions that express setup time and run-time as a function of the number of machines which is an inverse measure of the quality of the CNC machines the plant is using. Results in Table 1 show that increases in CNC quality significantly decrease setup and run times. The $\log$ (setup-time) regression shows that a 10 percent reduction in the number of machines (increase in $\mathrm{CNC}$ quality) reduces setuptime by 9 percent (Table 1, column 1). Equivalently, a decrease in the number of CNC machines from 6 (the mean and median for the data) to 5 reduces setup time by 56 minutes, relative to a median setup-time of 495 minutes. Moreover, the R-squared is large -- for the overall regression it is .60; for the within effects (i.e., by product) it is .42; and for the between effects it is .68. The effects are also sizable for $\log$ (run-time). A 10 percent decrease in machines (increase in CNC quality) reduces run-time by 6 percent. However, because typical run-times (at 46 minutes for the entire batch) are much shorter than setup-times, and because the typical batch size is very small in this plant, the most important quantitative gains are in setup-time reduction. Note that the time series that we have for most valve products is very short, and perhaps as a result, we find no strong time trend reduction in either setup-time (column 2) or run-time (column 5).

While the estimates from the product-specific regressions in Table 1 imply large reductions in production times, especially setup times, when the plant uses a smaller number of newer machines to produce a valve product, two factors determine the exact size of the $C N C$ quality coefficients in these regressions. First, the higher the quality of the new CNC machine introduced into the production process, the greater is the reduction in setup-time. Not all products use exactly the same CNC machines. The point estimates on the coefficient on the CNC quality variable in the Table 1 regressions reflect the average increase in quality of the CNC machines purchased. Second, the most complicated products that require especially long setups may benefit the most from purchasing new $\mathrm{CNC}$ machines to produce these products. For a typical product at this plant, a switch from an average set of older CNC machines to an average set of newer CNC machines reduces setup time by 56 minutes (Table 1, column 3).

\footnotetext{
${ }^{12}$ In our larger survey dataset that is described below we find that plants that reduce their number of machines to produce a given product between 1997 and 2002 are plants that also report purchasing new CNC machines during the same period. Purchasing new machines allows plants to use fewer new machines to make a given product.
} 
The regression results from this case study reinforce the observations that managers made during our plant visits. Improvements in CNC quality (as measured by the reduction in the number of machines used to produce a given product) reduce setup-time significantly. To a lesser extent, improvements in CNC quality reduce run time. The causal mechanism underlying the results of these simple regressions is clear: a reduction in the number of machines occurs only because the quality of the CNC technology is better. When a plant produces a given valve product with fewer machines that are easier to program, then setup-times go down. With this smaller number of faster machines, run times also go down.

\section{Theoretical Framework of the Impact of IT}

Valve manufacturing is a batch process. Products in many other manufacturing industries are also made in batches. Each compound in chemical production, each book in publishing, and each new piece of furniture in high volume furniture production is a new batch. Even in services, each new customer often creates a new 'batch' set of orders that require separate adjustments. In batch production the same equipment is used to manufacture the different product types, but the new product specifications require reconfiguring the specific operations of the machines. In all of these settings, just as in the econometric case study of the valve manufacturer above, the setuptime when machines are reconfigured from the requirements of one product run to the next is often a large part of overall production time. Even when setup time is not a large portion of total production time, it is still the focus of much of manufacturing, because setup time is a cost that may be reduced, whereas there may be limits on runtime reduction - as in our study, "you can only cut steel so fast."

We posit that an important consequence of the dramatic reductions in the price of information technology and the corresponding increases in new computer-aided production equipment is that setup costs are dramatically lower after firms adopt new production machinery. Previously, switchovers between product runs entailed a great deal of hands-on adjustments of machinery by knowledgeable craftsman who operated the machinery. Setups for new product runs are now programmable, made as easy as touching computer screen interfaces that dictate the operations of highly automated machine parts. Lower setup costs involving more flexible production machines facilitate a move toward greater customization as firms produce smaller batches of products tailor-made to the needs of specific customers. 
The primary point of the model we introduce in this section is that firms that introduce new IT-enabled production equipment are also changing their business strategy - competing less in terms of lowering the production costs of commodity products made in long batch runs, and more in terms of making customized products designed for specific customers that typically command higher prices. This change takes place in part because IT lowers the cost of changeovers between products. ${ }^{13}$

To clarify the tradeoffs that firms face with improvements in information technologies, we model the change in profits that would be expected from falling prices of information technology. Assume that there are two product classes - commodity products (co) and customized products $(\mathrm{cu})$. Commodity products are typically listed in a company's catalog and customers must order these products exactly as they are described in the catalog. Customized products may be variants of a commodity product but they are made to the customer's specification. Since customized products are made to fill a customer's specific order, they are made in shorter batch runs and have smaller batch size $\left(\mathrm{B}_{\mathrm{cu}}\right)$ than commodity products, which are made in longer batch runs and thus have larger batch size $\left(\mathrm{B}_{\mathrm{co}}\right)$. Assume for simplicity that these batch sizes are fixed for each product class and thus $\mathrm{B}_{\mathrm{cu}}<\mathrm{B}_{\mathrm{co}}$. Given these fixed batch sizes for the two classes of product, the firm maximizes profits, $\pi$, by deciding how many production runs of the customized product, $\mathrm{N}_{\mathrm{cu}}$, and how many runs of the commodity product, $\mathrm{N}_{\mathrm{co}}$, to undertake:

(1) $\pi=\mathrm{N}_{\mathrm{cu}} \mathrm{B}_{\mathrm{cu}}\left[\mathrm{P}_{\mathrm{cu}}-(\text { unit cost })_{\mathrm{cu}}\right]+\mathrm{N}_{\mathrm{co}} \mathrm{B}_{\mathrm{co}}\left[\mathrm{P}_{\mathrm{co}}-(\text { unit cost })_{\mathrm{co}}\right]-\mathrm{P}_{\mathrm{IT}} \mathrm{IT}$

where unit costs are a function of setup time $\left(\mathrm{S}_{\mathrm{co}}\right.$ or $\left.\mathrm{S}_{\mathrm{cu}}\right)$, runtime $\left(\mathrm{R}_{\mathrm{co}}\right.$ or $\left.\mathrm{R}_{\mathrm{cu}}\right)$, inspection time $\left(\mathrm{I}_{\mathrm{co}}\right.$ or $\left.I_{c u}\right)$, materials costs $\left(M_{c o}\right.$ or $\left.M_{c u}\right)$, design and sales time $\left(D_{c u}\right)$ :

(2a) (unit cost $)_{\mathrm{cu}}=(\mathrm{w}+\mathrm{r})\left(\mathrm{S}_{\mathrm{cu}} / \mathrm{B}_{\mathrm{cu}}+\mathrm{R}_{\mathrm{cu}}+\mathrm{I}_{\mathrm{cu}}\right)-\mathrm{M}_{\mathrm{cu}}-\mathrm{D}_{\mathrm{cu}} / \mathrm{B}_{\mathrm{cu}}$

(2b) (unit cost $)_{\mathrm{co}}=(\mathrm{w}+\mathrm{r})\left(\mathrm{S}_{\mathrm{co}} / \mathrm{B}_{\mathrm{co}}+\mathrm{R}_{\mathrm{co}}+\mathrm{I}_{\mathrm{co}}\right)-\mathrm{M}_{\mathrm{co}}$

So profits are

(3) $\pi=\mathrm{N}_{\mathrm{cu}} \mathrm{B}_{\mathrm{cu}}\left[\mathrm{P}_{\mathrm{cu}}-(\mathrm{w}+\mathrm{r})\left(\mathrm{S}_{\mathrm{cu}} / \mathrm{B}_{\mathrm{cu}}+\mathrm{R}_{\mathrm{cu}}+\mathrm{I}_{\mathrm{cu}}\right)-\mathrm{M}_{\mathrm{cu}}-\mathrm{D}_{\mathrm{cu}} / \mathrm{B}_{\mathrm{cu}}\right]$

$$
+\mathrm{N}_{\mathrm{co}} \mathrm{B}_{\mathrm{co}}\left[\mathrm{P}_{\mathrm{co}}-(\mathrm{w}+\mathrm{r})\left(\mathrm{S}_{\mathrm{co}} / \mathrm{B}_{\mathrm{co}}+\mathrm{R}_{\mathrm{co}}+\mathrm{I}_{\mathrm{co}}\right)-\mathrm{M}_{\mathrm{co}}\right]-\mathrm{P}_{\mathrm{IT}} \mathrm{IT}
$$

\footnotetext{
${ }^{13}$ The idea that the firm's strategy should change in response to an input price change was emphasized in exactly our context by Milgrom and Roberts (1990) in their description of the shift to "modern manufacturing" resulting from falling prices of IT. In their model, the entire "system" of production changes, resulting in more frequent product redesign, higher product quality, more frequent setups of smaller batches, lower inventories and faster shipment times.
} 
where $\pi \equiv$ profits

subscripts $c o \equiv$ commodity product, $\mathrm{cu} \equiv$ customized product

$\mathrm{S}_{\mathrm{j}} \equiv$ hours to setup machine to run a batch of product; $j=c o, c u$

$\mathrm{R}_{\mathrm{j}} \equiv$ hours to run each piece of product; $j=c o, c u$

$\mathrm{I}_{\mathrm{j}} \equiv$ hours to inspect each piece of product; $j=c o, c u$

$\mathrm{D}_{\mathrm{cu}} \equiv$ cost of product design and product promotion (only customized products have these costs)

$B_{j} \equiv$ average batch size (number produced per scheduled batch) $j=c o, c u$

$N_{j} \equiv$ number of batches of product $j ; j=c o, c u$

$\mathrm{M}_{\mathrm{j}} \equiv$ materials costs per unit; $j=c o, c u$

$P_{j} \equiv$ average price of product $j, j=c o, c u$

$w \equiv$ wage rate

$r \equiv$ maintenance cost of capital

$\mathrm{P}_{\mathrm{IT}} \mathrm{IT} \equiv$ price of new IT-imbedded machines times the quantity of IT-embedded machines

Equation (1) simply emphasizes that profits in the short run are a function of the difference between the revenues and the time costs of production, minus the materials costs and the cost of the CNC machines. The time costs of production are the wage and the rental cost of capital for the time that it takes to produce the product. Thus, productivity is increased if production time falls. Finally, for customized products, we assume that there is a design and advertising cost, $\mathrm{D}_{\mathrm{cu}}$, reflecting the cost of the specialized design of the product and the cost of finding customers seeking custom-designed products.

Underlying (3) is the assumption that each hour of machine time requires an hour of operator time, or that:

(4) $L_{j}=\left(l_{1} \mathrm{~S}_{\mathrm{j}}+l_{2} \mathrm{R}_{\mathrm{j}} B_{j}+l_{3} \mathrm{I}_{\mathrm{j}} B_{j}\right)$; for $j=c o, c u$

where $l_{1}=l_{2}=l_{3}=1$ if one person runs each machine, which is typically true. Next, assume that all three components of production time are a function of IT-imbedded capital and other variables. Thus, while labor hours in (4) are a fixed percentage of production time, we also assume that a more skilled worker or highly trained operator can do a setup in less time: ${ }^{14}$

$$
\begin{aligned}
& \mathrm{Sj}=\mathrm{f}^{\text {Set }}\left(I T_{j}^{\text {Set }}, \text { Skill, } X\right), \quad \text { for } j=c o, c u \\
& \mathrm{Rj}=\mathrm{f}^{R}\left(I T_{j}^{R}, X\right), \quad \text { for } j=c o, c u \\
& \mathrm{Ij}=\mathrm{f}^{I}\left(I T_{j}^{I}, X\right), \quad \text { for } j=c o, c u
\end{aligned}
$$

\footnotetext{
${ }^{14}$ One of the plant managers that we visited explained that the skill of the operator is very important in the setup component of production time, even on the brand-new machines.
} 
where $I T_{j}^{S e t}, I T_{j}^{R}, I T_{j}^{I}$ are the IT-imbedded machinery that are used in the setup, running, and inspection of the product, and $X$ is a vector of control variables.

With this model of the manufacturing process, how does the falling prices of IT, that is, of more sophisticated CNC machines (i.e. those with greater computerization embedded in them) affect the firm? First, firms purchase more IT because IT is cheaper, so a decrease in $\mathrm{P}_{\text {IT }}$ raises IT (all else constant). Second, more IT is purchased because profits rise due to falling production costs. Based on evidence from our plant visits we assume that production process efficiency should rise, or setup time, runtime and inspection time should fall when IT machinery relevant to these processes is adopted, i.e. $\partial \mathrm{S}_{\mathrm{j}} / \partial(\mathrm{IT})<0, \partial \mathrm{R}_{\mathrm{j}} / \partial(\mathrm{IT})<0$, and $\partial \mathrm{I}_{\mathrm{j}} / \partial(\mathrm{IT})<0$ in equations (5)-(7).

Third, the firm makes a strategic move towards producing customized products. This change occurs because IT reduces the cost of setup time. Our plant visits indicated that setup time is the most important controllable component of production time and that new computerized IT has the biggest effect in lowering setup time. As setup time falls, the unit cost of production falls, and as equation (2) shows, the reduction in unit costs due to a reduction in setup time is greater for customized products than for commodity products: ( $\partial$ (unit costs) $\left./ \partial S_{j}=1 / B_{j}\right)$ because $\mathrm{B}_{\mathrm{cu}}<\mathrm{B}_{\mathrm{co}}$. (i.e. setup costs are a bigger fraction of unit costs for customized products). Given this falling cost of customized products relative to commodity products, plants increase their production of customized products, all else constant. The degree to which the firm moves to customized production and purchases new IT depends on the relative weights of all of the above factors, including the size of the technology shock and falling prices. ${ }^{15}$ Even if customized products and commodity products are produced in the same batch sizes so that the impact of IT

\footnotetext{
${ }^{15}$ Thus, firms move towards customized production if they are price takers and product prices are unchanged. (Note also that firms are likely to be moving towards customized products because the price of commodities is falling due to lower labor costs for unskilled labor abroad.) In their model, Milgrom and Roberts (1990) make the assumption that their multi-product firm faces a downward sloping demand curve and then solve for the optimal amounts of output and other control variables. Likewise, to solve for the optimal amounts in our model, we would need to place constraints on the model that would limit the optimal output, such as downward sloping product demand and/or nonlinear adjustment costs for changing the plant size or for finding new customers. For the valve industry, we envision both of these constraints. That is, firms are price takers for small increases in their output, but as output rises too much, the market is saturated and prices fall. Similarly, we are modeling the short run decision to become more customized, and in the short run, the costs of significantly increasing the size of the plant or seeking large numbers of new customers are accelerating, and therefore limit the increase in the optimal amount of customized product that is produced. Thus, our model of changes in product mix and IT purchase should be considered a model of short-run marginal changes.
} 
on unit costs (net of design costs) is the same for both classes of products, plants would increase their customized production if customized products sell at higher prices. ${ }^{16}$ Finally, another reason that IT will induce a move towards greater production of customized products is that IT lowers design costs which, according to our model, are only relevant for customized products.

Based on this simple model, we will test the following hypotheses:

H1. Given falling costs of IT-embedded machines, there will be an increase in the adoption of IT-imbedded machinery. In the valve making industry, the IT-embedded machines include equipment like new CNC machines, new 3D-CAD software, FMS, and computerized inspection equipment.

H2. New IT-embedded machines improve production process efficiency - i.e., productivity rises.

H3: New IT promotes increased production of customized products - i.e., there is product innovation.

H4. Given rising short run profits from product customization, plants that survive in the industry over time should be those that produce customized products (or that move towards product customization), and those plants that enter the industry should produce more customized products. $^{17}$

Finally, we posit a fifth hypothesis that is not considered directly in the model.

H5: IT adoption may require new HRM practices and new worker skills.

\footnotetext{
${ }^{16}$ Customized products are likely to sell at higher prices than commodity products because of greater competition in the commodity market, especially from foreign producers who have lower labor costs.

${ }^{17}$ There are many alternative models that can produce implications for which firms should produce customized products, given different competitive conditions surrounding the value of customization and different assumptions about the production function, production adjustment costs, etc. See, for example, the model of "competitive customization" by Pardaktark and Mendelson (2004) and the work cited therein.
} 
While the role of HRM practices is not considered in the model above, a number of models (Milgrom and Roberts, 1990; Bresnahan, Brynolfsson and Hitt, 2002) conclude that the adoption of highly automated and technically complex manufacturing equipment may require the adoption of new types of work practices and require new sets of skills from workers. The data collected for this study permit us to examine these further hypotheses that suggest that adoption of new technologies will coincide with changes in HRM practices and in the kinds of skills workers need to operate new technologies.

\section{The Valve-Making Industry Survey and the LRD Matched Data}

The plant visits and interviews with industry experts identify concrete examples of new IT-based equipment and the parts of the overall machining process these IT advances impact. Observations from this field research are supported by the econometric case study results shown in Table 1. To examine the impacts of IT investments on performance more broadly throughout the entire industry, we developed a customized survey for valve plants. This survey measures: a) production process improvements in each of the three production stages; b) increasing customization of a plant's valve products; and c) investments in new IT-enhanced production machinery. The survey is also designed to look at a broader set of possible changes associated with new IT investments and also asks for information on worker skills and HRM practices.

The Sample of Valve Industry Plants. After conducting the field research, we designed, pre-tested, and conducted a customized industry survey in $2002 .{ }^{18}$ To identify the population of U.S. valve-making plants for this survey, we collected contact information from Survey Sampling, Inc. for any plant in a valve-making industry class (SICs 3491, 3492, 3494, and 3593) with more than 20 employees. Of a potential universe of 416 valve making plants of this size, 212 plants, or 51\%, provided responses to the survey questions described in this section via telephone interviews. ${ }^{19}$ Empirical results in the study are based on the responses from these 212 valve-making plants.

\footnotetext{
18 The Office for Survey Research at the Institute for Public Policy and Social Research at Michigan State University conducted the pre-tests and final surveys by telephone from July 31, 2002 through March $30,2003$. Interviews lasted an average of 20 minutes with an average of 7.6 phone contacts needed to complete the survey.

${ }^{19}$ Of 762 plants that Survey Sampling Inc. lists in the four valve-making SIC classifications, 200 were determined to have no production and another 70 were no longer in business. Assuming a similar rate of survey ineligibility for other plant names that could not be contacted yields the number of 416 valve-making plants.
} 
Measures of Production Process Efficiency. As the field research and econometric case study reveal, plants produce a range of valve products. This product heterogeneity is an important consideration in developing measures of process efficiency. We therefore use a product-specific measure of efficiency gains in the plants' machining processes. We asked each respondent to look up data for "the product you have produced the most over the last five years" for the following key indicators of production efficiency:

Setup-Time: About how much setup-time does (did) it take to produce one unit of this product today (and in 1997)?

Run Time: About how much run time does (did) it take to produce one unit of this product today (and in 1997)?

Inspection Time: About how long does (did) it take to inspect one unit of this product today (and in 1997)?

Measures of Product Customization. Increases in customization imply changes in the number of products a plant makes. Unlike the process efficiency measures that pertain to one product, these are plant-wide variables. Based on discussions with managers, we measure the extent to which plants are customizing products for specific needs of customers with the question:

Percent Catalog: In 2002 (1997), what percentage of your customer orders are directly from your catalog with no design change?

There were 197 responses for the 2002 question, but only 70 for 1997 data. However, virtually all respondents answered a separate survey question that asked if the percent of orders from the catalog increased, decreased or stayed the same between 1997 and 2002 and we use this question for longitudinal analyses of changes in customization between 1997 and 2002. We also report some longitudinal analyses for the 1997-2002 change in percent catalog in which we use the 2002 value of percent catalog for 1997 for those plants that report that percent catalog did not change over this five year period. ${ }^{20}$

\footnotetext{
20 We also considered batch sizes in the plant as an alternative measure of customization since batch size will fall as customization increases. However, managers noted that when new technologies reduce setup times, they will produce the exact same product in smaller batches to fill specific orders for that product from different customers more quickly. A decline in batch size may reflect a move to just-in-time production methods. Managers therefore felt customization was captured better by whether they had to add specific features to standardized values shown in product catalogs. Still, we collect data on batch size with the survey question: Batch Size: What was the typical batch or lot size of the products that you produced in 2002 (1997)? Particularly for 1997 cross-section analysis where data on percent catalog are missing for many respondents, we use data on batch size.
} 
Information Technology Measures. The survey asks several questions to measure investments in the specific IT-enhanced equipment identified during our plant visits:

Number of CNC Machines (CNC Quality): In order to produce one unit of this product today (and in 1997) how many CNC machines do (did) you employ?

New CNC Machines: How many CNC machines does the plant have and how many are less than 5 years old (newcnc), 5 to 10 years old, and more than 10 years old?

Flexible Manufacturing Systems (FMS): Does the plant have FMS technology (where two or more machines are controlled by computers) and what was the year of adoption?

Automatic Inspection Sensors (Auto Sensors): Does the plant have automated inspection sensor equipment and what was the year of adoption?

Three Dimensional CAD software: Does the plant use three-dimensional CAD software for designing new products and in what year was this software first used?

The first IT question above concerning "number of CNC machines" is a product-specific question and pertains to the plant's main valve product over the last five years. As in the econometric case study, a decrease in the number of CNC machines used to produce a given product indicates the use of more technologically advanced $\mathrm{CNC}$ machines, and this productspecific measure is used in the product-specific production time regressions. Ideally, we would measure whether the $\mathrm{CNC}$ machines used to make the product have specific IT capabilities (e.g. does the IT on this machine allow the machine to bore holes on multiple axes at the same time), but the number and detail of these questions made them infeasible for a broad-based survey of the industry. As in the econometric case study, we use a reduction in the number of machines used to produce a given product as a direct indicator of the use of newer, more advanced CNC machines. Data on other IT variables from this survey support this contention. The correlation between a dummy variable measuring whether the number of machines used on the main product went down and a dummy variable for whether the plant bought a new CNC machine since 1997 is significant at the 5\% level. A reduction in the number of machines used to produce the plant's main product reflects the purchase and use of newer, more technologically sophisticated CNC machines. The other IT questions in the survey measure plant-wide characteristics. Other plantlevel survey questions concerning human resource management practices, skill demand, and competitive market conditions are described below with the empirical results. 


\section{$\underline{L R D \text { Survey Data and Sample }}$}

In the analysis below, we complement data from our valve industry survey with data on valve making plants from the Census Bureau's Longitudinal Research Database (LRD). The LRD is a panel data set constructed from Census of Manufacturers survey data. To date, only data through 1997 are available from the Census of Manufacturers, so we examine data for the 1997 cross-section of plants, and conduct longitudinal analyses using the LRD for the 1992-1997 time period. We use the LRD data primarily to examine trends in exit and entry from the broader industry and to test whether the industry is moving in the direction of having more customized valve producers during the 1990's.

\section{Trends in IT Investments, Productivity, and Work Organization in the Valve Industry}

We introduce the empirical analysis by presenting descriptive statistics on trends in IT adoption. We also present changes in process efficiency, product customization and work practices for the survey sample.

The Adoption of IT-Embedded Production Machinery

Our survey results confirm the most basic hypothesis of this study (H1) - the valve industry has witnessed a dramatic increase in the adoption of four types of IT equipment over time as a result of falling prices of computerized products (see Figure 4, and Panel A of Table 2). ${ }^{21}$ Since 1980, the use of all four types of IT-enabled equipment has increased. The highest rates of adoption for the plant's first CNC machines occurred during the 1980's, but plants continued to invest heavily in new CNC machines throughout the 1990s --74 percent of plants purchased new CNC machines from 1997-2002 (Table 3, Panel A). As described in section II above, newer CNC machines have superior production capabilities due to advances in IT. Investments in other new computer-based technologies - automated inspection sensors, flexible manufacturing systems, and 3D-CAD - show the largest growth after 1995. About half of all new IT adoption occurred during the five-year period from 1997 to 2002 that we use for the regression analysis below: FMS technology, automated inspection sensors, and 3D-CAD technology were adopted by an additional 15\%,14\%, and 39\% of our sample of valve making establishments (Table 3, Panel A). Moreover, CNC quality rose, as measured by the number of

\footnotetext{
${ }^{21} \mathrm{We}$ do not have hedonic price indexes for these machines that document falling prices for each 'unit' of machine quality, but are assured by industry experts that the falling cost of IT (of chips, storage, speed) has reduced prices relative to benefits in these machines.
} 
CNC machines it takes to produce a given product: on average, it took 19 percent fewer machines to produce a given valve product in 2002 compared to 1997 (Table 3, Panel B). The conclusions from Tables 2 and 3 are clear: during the 1990s, plants in the valve-making industry invested heavily in new computer-based production technologies.

Trends in Measures of Production Efficiency and Product Customization

On average, plants realized large declines in production times at each stage of production when making their most common product (Figure 6, and Panel $\mathrm{C}$ of Table 3). The largest decline is in the setup stage. Moreover, the 1997-2002 period is marked not only by improvements in process efficiency but also greater customization as captured by trends in percent of production directly from catalog products (Table 3, Panel D). For the 70 plants that reported actual data on the percent of orders from catalogs in 1997 and 2002, percent catalog fell by 5.7\%. Among the 184 plants that reported information on the direction of change in percent catalog, twice as many plants report a decrease in the percent of orders from catalogs as reported an increase (25 percent vs. 13 percent respectively). Over this five-year period, 62 percent of plants report no change in the percent of orders coming directly from their catalogs. While batch size changes may reflect greater use of just-in-time production methods in which a given product is produced in smaller batches as well as a shift to the production of more customized products, the typical batch size of plants products also declined since 1997.

Trends in the Adoption of New HRM Practices

Regarding the use of new human resource management practices (HRM), the use of teams, training programs and bonus/incentive pay plans all increased substantially since 1980 with the highest rates of adoption of these practices occurring after 1990 (Figure 7, and Panel B of Table 2). When we examine the 1997 to 2002 period for which we have information about a broader set of HRM practices, similar upward trends are evident (Table 3, Panel A, lines 6-10). Valve plants increasingly adopted new training programs, more team-based methods of job design, and more meetings with operators. Incentive pay plans, excluding bonus payments, are less common than the other HRM practices. ${ }^{22}$ Basic training programs in reading and math,

\footnotetext{
${ }^{22}$ Interviews suggested that direct incentive pay is difficult to adopt in an industry that makes customized products. The increase in the use of incentive pay is smaller than the increase in other HRM practices in the valve industry. By 2002 , incentive pay is used by $31 \%$ of plants and special bonuses by $36 \%$ of plants, so about $50 \%$ of plants have one or the other (see Table 2), but interviews suggest that these incentives are a very small percent of total pay and are used rather erratically. As a result, we do not focus on the incentive pay plans in our HR analysis below.
} 
technical skills training, and teams were adopted by $12 \%, 21 \%$, and $30 \%$, respectively, between 1997 and 2002.

Overall, the patterns in Tables 2 and 3 show that the trends in IT investments, productivity measures, and new HRM practices mirror trends observed in the broader U.S. economy. The 1990's in the valve industry is a decade marked by rapid adoption of new machinery that incorporates many IT-based technological improvements, significant improvements in productivity of operations, increases in product customization, and a growing reliance on new methods of work organization.

These trends are consistent with studies using more aggregated data. They demonstrate that production efficiency gains and product customization increases are happening at the same time that the industry is investing in new IT-enhanced machinery and new HRM practices. However, the empirical work to follow will use these plant-specific data from the valve industry to conduct tests that are not possible with more aggregate data. Specifically, we examine whether the improvements in various aspects of machining times or increases in customization over this period are concentrated in those plants that have made investments in these new technologies and work practices. Also, though not reported in Tables 2 and 3, it is not the case that some plants adopted all of the technologies and practices while others adopted none. Because different plants adopted different pieces and combinations of IT equipment, the models will also be able to make a particularly discriminating test of the effects of the IT measures on productivity. Specifically, the econometric models examine whether specific pieces of equipment that impact individual stages of production (e.g., automated inspection equipment and the inspection stage) affect the specific stage of production in which it is located.

\section{Estimates of the Determinants of Productivity at the Product Level}

We turn now to estimating models of the determinants of the improvements in process efficiency that were documented in Table 3. We estimate the following first difference productivity models in which time-based efficiency measures are expressed as a function of the adoption of new machining technologies and new HRM practices to see if production efficiency gains occur in those plants that adopt new technologies or work practices.

(7) $\Delta \ln ($ ProductionTime $)=a+\mathbf{b}_{1} \Delta($ NewTechnology $)+\mathbf{b}_{2} \Delta(\mathbf{N e w H R M})+\mathbf{b}_{3} \mathbf{X}+\mathrm{e}_{1}$ 
The dependent variable in (7) is the log change in Production Time between 1997 and 2002 where Production Time refers to setup-time, run time and inspection time. These measures refer to production times for one product - the product that the plant produced the most in the 19972002 period. The vector $\Delta$ (NewTechnology) measures the 1997-2002 adoption of new technologies expected to reduce these machining times - the adoption of higher-quality CNC machines (as measured by the change in the number of CNC machines needed to produce the plant's main product), FMS, and automated inspection sensors. The vector $\Delta(\mathbf{N e w H R M )}$ measures the 1997-2002 adoption of new HRM practices, such as work teams and training programs, and $\mathbf{X}$ is a vector of controls including the age of the plant, union status, and plant size measured as number of workers to test whether the change in production efficiency is affected by these additional factors.

\section{Estimates of the Effects of Specific Valve-Making Technologies on Machining Times}

The regression results reported in Table 4 support Hypothesis 2. Investments in new ITmachinery have improved productivity by reducing production times in all stages of production. The results are remarkably straightforward and striking: the adoption of new technologies into a given stage of the machining process reduces production times in that stage significantly. As in the econometric case study above, the variable "Increase CNC Quality" is the reduction in the number of CNC machines used to produce the product. The adoption of higher-quality CNC machines reduces setup-time (column 1) and runtime (column 2). Both of these results for this industry-wide sample of valve plants mirror the results from the econometric single-plant case study reported in Section II. Setup-time and runtime also decline significantly in plants that adopt FMS technology. Inspection time declines with the introduction of new automated inspection sensors (column 3). The basic pattern of results in Table 4 can be summarized simply. New IT-based production machinery improves the efficiency of the stage of production in which it is involve. It does not improve the efficiency of phases of machining in which it is not involved.

The theoretical discussion of section III draws special attention to reductions in setup times. There, we argued that reductions in setup time due to new IT investments make product changeovers faster and cheaper, resulting in a move toward greater customization. These estimated savings in setup times from the adoption of more advanced CNC machines shown in column 1 of Table 4 are sizable. According to the means on production times reported in Table 
3, setup times in 1997 were the largest component of overall production time, accounting for almost one-half of overall production time. We can use the coefficient in column 1 of Table 4 to calculate the impact of IT investments on setup time. Among plants that experienced an improvement in CNC quality as measured by a decrease in machines after 1997, the median change in $\ln$ (machine) is -.54 (or approximately 1.7 machines). Using the coefficient on CNC quality in column 1 of Table 4, this implies a reduction in setup time of .42 ln-units, or 1.52 hours, relative to an initial median setup-time for these plants of 5 hours. Introducing flexible manufacturing systems (FMS) reduces setup-time by .184 ln-units or 1.2 hours. Thus, investments in IT account for a large part of the overall reduction in setup-times between 1997 and 2002 .

The efficiency gains resulting from the improvement in CNC quality produce increases in net revenue for two reasons. First, hourly labor costs per valve fall. Since machine time is labor time (one person per machine), labor costs fall when machine time falls, and thus net revenue per unit of product rises, all else constant. Since materials costs are unchanged, this should show up entirely as profits (minus the costs of the new IT and assuming no change in competitive conditions). Second, reduced setup time and runtime mean that the plant can run more jobs per year on that one machine. Plants that experienced an increase in CNC quality (due to the purchase of a more sophisticated CNC machine) saved 1.52 hours in setup time. Based on the coefficient on CNC quality in column (2) in Table 4, they also experienced a reduction in runtime of 4.2 minutes per valve. Using the median batch size of 150 , this translates into a reduction in total runtime of 10.5 hours per product. Combining the setup time and runtime savings results in a total time savings of 12.02 hours per product produced. These time savings would enable the plant to produce an extra 0.88 batch each month or 10.56 additional batches each year, resulting in a $28 \%$ increase in revenue (though in this case, material input costs would also rise for the production of the new output). ${ }^{23}$

\section{Estimates of the Effects of HRM Practices on Machining Times}

According to our theoretical framework, production time (and, in particular, setup time) is likely to be shorter if the plant has more skilled operators (Hypothesis 5). The results in Table

\footnotetext{
${ }^{23}$ Assuming a 40-hour workweek and 4.33 weeks per month results in 173 hours per month. In 1997, it took 55 hours to setup and run the median batch; in 2002, it took only 42.98 hours. Hence, in 1997, 3.145 batches could be completed in one month while in 2002, 4.025 batches could be completed. This means that an additional 10.56 batches, or 1584 valves, could be produced each year.
} 
4 show that plants that introduce technical training programs also realize an additional reduction in setup times and runtimes. While these efficiency regressions find no effects of teams, it is important to remember that these models pertain only to the efficiency gains over time for one specific product, not the overall efficiency of the plant. Teams may be less likely to have a direct effect on product efficiency for a run of a single product than on overall plant efficiency. The results in Table 4 demonstrate that initiatives designed to improve the specific skills needed to operate new technologies in the plant are in fact the initiatives that improve the speed of machining operations during a given product run. ${ }^{24}$

Assessing Potential Biases in Estimated Productivity Effects of IT and HRM

The Table 4 results indicate that new IT equipment improves the efficiency of the production stages in which it operates. Technical training programs have their own independent effect on setup and run times. Since the IT equipment and HRM practices are not universally adopted, the question naturally arises whether the estimated regression coefficients on the IT and training variables are biased estimates of the effects that these variables would have on production process efficiency of plants that have yet to adopt them. Would plants that have yet to adopt the new technologies actually enjoy the estimated improvements in manufacturing times were they to adopt the new IT equipment or HRM practices? Or is the reason behind the nonadoption of new IT and new HRM practices in some plants the fact the non-adopters would not experience the same improvements in efficiency?

Given the nature of the data used in the analysis and the patterns of results, we suspect that certain potential sources of bias are not important considerations. First, bias in the coefficients from simultaneous determination of the dependent and independent variables is unlikely. Consider, for example, the setup-time regression. There is no reason to expect a decline in setup-time to cause a decline in the number of machines in use. The only way that setup-time can be reduced over time for the same product is if there is new technology or if workers are better able to use the existing technology. Moreover, the efficiency measures are typical production times, not today's times, so these measures are not affected by unanticipated

\footnotetext{
${ }^{24}$ Unlike others who have found significant interaction terms between IT and HR practices using plant-level productivity measures (e.g.. Bresnahan, Brynjolfsson and Hitt, 2002), we do not find significant coefficients on interaction terms between IT and technical training in the context of product-specific efficiency models that focus on producing one product on a few machines. However, we later show that, at the plant level, the adoption of IT and new HRM is highly correlated.
} 
machine failures that could be correlated with changes in input use including our IT measures. Thus, potential simultaneity problems are not apparent with these data.

Second, the pattern of results in Table 4 that show IT equipment affecting some stages of the production process and not others suggests that many types of omitted variable bias are also not important concerns. For example, automated inspection sensors reduce inspection time but not run time or setup-time. An omitted plant-wide variable, such as manager or production worker quality, is unlikely to cause this pattern. If the estimated effect of new inspection equipment simply reflected the fact that plants with this equipment had better managers or workers, then the automated sensor variable would reduce production times in other stages as well. Thus, there is no one plant-wide omitted variable that could explain the significant effects of all the IT-based variables. One would need to identify a series of omitted variables with different correlations with the IT investments to produce omitted variable biases on the IT coefficient for each stage of production. ${ }^{25}$

A third source of bias is selection bias. The Table 4 regressions estimate the average expected productivity gains among adopters - that is, the average "treatment of the treated" effect. $^{26}$ These coefficient estimates are average expected efficiency gains for those valvemakers that adopted the IT between 1997 and 2002 given the typical quality of their new CNC (or FMS or inspection) equipment adopted in that period and the typical level of product complexity among the IT adopters. If technology adopters differ from the non-adopters according to unmeasured characteristics, and these characteristics could increase the magnitude of the effects of IT on production times, then the treatment of the treated estimates will overstate the effects of IT on production times among the plants that have yet to adopt the IT.

The data collection protocol for this study addresses this concern to some extent. By focusing on plants in one narrowly defined manufacturing setting, we eliminate many sources of unobserved heterogeneity that could affect the magnitude of the effect of IT investments on production times. Still, the homogeneous sample does not eliminate concerns about selection bias since these are not experimental data with random assignment of IT across plants. In this

\footnotetext{
${ }^{25}$ The estimated productivity gains from the increased quality of CNC machines could reflect improvements in engineering work on the $\mathrm{CNC}$ machines as well as the gains due to computerization of the machines since the use of more advanced CNC's may have to be accompanied by better engineering. Here, however, the interpretation would still be that improvements in the $\mathrm{CNC}$ technology matter, but these technological improvements are accompanied by changes in engineering quality.

${ }^{26}$ For a comprehensive review of alternative treatment effects see Heckman, LaLonde, and Smith (1999) and Heckman (1990).
} 
study's intra-industry sample, an important reason why adopting plants might experience greater reductions in production times than non-adopting plants is that these effects of IT may vary with differences in product attributes. For example, the Table 4 productivity regressions do not control for differences in attributes reflecting customization of the valve plant's main products, and thus it is possible that the adoption of new $\mathrm{CNC}$ machines could reduce setup-times more for more complex valve products with more customized features.

We use our survey data to examine whether the level of product customization in 1997 prior to the adoption of new machines affects the size of the subsequent reductions in production times due to IT adoption. To test for this type of selectivity, we estimate two additional sets of models that make use of the survey's measure of a plant's level of product customization prior to any purchases of new IT in the 1997-to-2002 period - the percentage of orders directly from the company's valve catalog in $1997 .{ }^{27}$ First, we re-estimate the Table 4 change-in-production time models but add an interaction term between the 1997 level of the percent catalog variable and the various IT adoption variables. For example, in a setup time model, if the adoption of a new CNC machine causes a larger reduction in setup time for more customized products, then the coefficient on an interaction between the percent-catalog-in-1997 variable and the increase-inCNC-quality between 1997 and 2002 variable in this change-in-setup-time model would be positive. $^{28}$ Second, we examine whether the value of the percent-catalog-in-1997 variable predicts adoption of new IT-enabled machinery after 1997. If plants with lower levels of the 1997 percent catalog variable expect larger reductions in production times when they purchase new IT equipment, then these plants would be more likely to adopt.

When we estimate these two sets of models, we find no evidence that previous customization levels affect either the subsequent adoption of new IT or the magnitude of the reductions in production times when IT is adopted. The interaction terms between percentcatalog-in-1997 and IT adoption variables are insignificant in setup time and runtime models, ${ }^{29}$

\footnotetext{
${ }^{27}$ To create the 1997 percent catalog variable for the largest possible sample, we set the 1997 value of percent catalog equal to the 2002 value of the percent catalog for any plant that meets the following two conditions: (1) the 1997 percent catalog variable is missing; and (2) the respondent reports that the percent catalog remained the same between 1997 and 2002.

${ }^{28}$ These regressions are still not the ideal tests of whether new CNC machines cause bigger reductions in setup times or run times for more highly customized products because the dependent variables in the regressions measure setup and run times for the plant's main product and the percent catalog variable pertains to all of the plant's products.

${ }^{29}$ We find an exception to this pattern for the change-in-inspection-time equation, where the adoption of new automated sensors has larger effects in plants with high values of percent catalog. The coefficients (and standard
} 
and plants with higher 1997 values of the percentage catalog variable are not any more or less likely to adopt new IT (as measured by the adoption of new CNC's, FMS, or automated inspection sensor technology after 1997). It is important to note that these models are not tests of whether the adoption of IT promotes further customization (that is, whether adoption of new IT after 1997 affects the change in a plant's product customization between 1997 and 2002). These models only show that plants with either high or low values of the percent catalog in 1997 are equally likely to adopt IT and experience future gains from customization that new IT allows. In the next section, we present models that test the hypothesis that the adoption of new IT after 1997 leads to a subsequent increase in customization (a decline in the percent catalog variable between 1997 and 2002), regardless of the 1997 level of the percent catalog variable.

Still, before we examine this hypothesis about IT adoption and subsequent changes in product customization, it is important to address the question of what accounts for the lack of IT adoption among some valve plants. If the estimated "treatment of the treated" effects reported in Table 4 do provide reasonable estimates of the reductions in production times that non-adopters would experience, why don't all valve plants make these purchases? The literature on technology adoption identifies several reasonable explanations. For example, some valve plants may face greater adjustment costs than other plants after they adopt IT, perhaps due to an older workforce or a plant layout that is less flexible. Here, the IT investments could still produce the kinds of reductions in setup-times and run times implied by the Table 4 regression coefficients, but the "net returns" (i.e., returns after accounting for adjustment costs) would be less for non-adopters than the adopters. ${ }^{30}$ The literature on technology adoption also suggests that some plants may choose to delay IT purchases until more sophisticated machinery is available because IT prices keep falling and IT capabilities keep improving. Here, the current non-adopters would actually experience bigger reductions in production times when they adopt because they will be implementing superior technologies. ${ }^{31}$

errors) on the "newauto" and "newauto * 1997 percent catalog) variables, respectively, are: $\quad-.075$ (.522) and -.014 (.007). Only the coefficient on the interaction term is significant at the .05-level.

${ }^{30}$ There is a substantial literature emphasizing that transition costs or adjustment costs may play a large role in the adoption of new technologies (Bresnahan and Greenstein, 1996; David, 1986; Rose and Joskow, 1990; Karshenas and Stoneman, 1993; Stoneman, 1983).

${ }^{31}$ For example, see the discussion in footnote 10 supra regarding the capabilities of the most recent inspection technologies. We expect even bigger productivity gains in the inspection phase of the production process when a plant puts these superior inspection technologies to use. 
In sum, the homogeneous nature of the sample that eliminates many sources of unobserved heterogeneity and the results from models that investigate whether plants with higher levels of product customization in 1997 enjoy larger reductions in production times after adopting IT help mitigate concerns about selection bias in the estimated coefficients on the IT variables in the Table 4 models. If selection effects in IT adoption do not provide the best explanation for why some valve plants have yet not adopted new IT-enhanced machinery, then more widespread adoption may occur in the future as adjustment costs fall, as technology improves, or as prices fall. Still, it is important to reiterate that the safest conclusion is that the Table 4 regressions provide evidence of sizable and significant "treatment of the treated" effects. At a minimum, reductions in production times after the adoption of IT-enhanced production equipment are large among those plants that chose to purchase this capital.

\section{The Gains to IT and Customization in the Valve-Making Industry}

Another reason the regression estimates in Table 4 will understate the overall gains from IT is that these regressions only estimate reductions in production times on a plant's main product. But as the model in Section III implies, new IT is also valuable because it allows plants to design and make new valves that are more complex. These effects of new IT are not captured in any estimated reduction in the time it currently takes to produce the plant's single most common valve product. In this section, we analyze the effect of IT-enhanced equipment on increased product customization. While the analyses in Section V and VI support two hypotheses in the Section III model, that falling IT prices increase the adoption of IT (H1) and new IT-based machines raise production line efficiency $(\mathrm{H} 2)$, the empirical work in this section assesses two additional hypotheses from the model: (H3) product customization will rise when plants invest more in new information technologies; and (H4) plants adopting a customization strategy should have lower exit rates and higher entry rates in the industry over time. Unlike the hypothesis concerning the effects of IT on production process times that we test with productspecific data for a plant's main product, we test these hypotheses with plant-level data since these hypotheses cannot be tested with data on a single product that has a fixed degree of customization.

The extent to which a plant customizes its products is measured in our survey with questions on the percent of the firm's output that is ordered directly from their catalog 
(PCTCAT). Because many respondents did not report a 1997 value of this variable, we measure the changes in customization of production in a plant between 1997 and 2002 with the related survey question that asks whether the percent of output from the catalog increased, decreased, or stayed the same over this period which was answered by nearly all respondents. The dummy variable for an increase in product customization (percent catalog down) equals one if the plant reports that the percentage of output ordered from their catalog fell between 1997 and 2002.

The IT measures that are most likely to facilitate a move towards customization are 3DCAD and new CNC machines. The former reduces the time it takes to translate a customer's specifications into an actual product design thereby making it easier for the plant to produce products that are not in its catalog. Since new CNC machines reduce setup-time, this should also make it easier for the plant to accept orders for custom products. We would not expect flexible manufacturing systems or automated inspection sensors to have an effect on product customization. The results in Table 5 show that the introduction of 3D-CAD and the purchase of a new CNC machine are both associated with an increase in product customization, as reflected in the decline in the percentage of orders directly from the plant's catalog. ${ }^{32}$ Not only do data on the time trend in catalog orders in this industry show that many more plants are decreasing catalog orders than are increasing them, the evidence in the regressions demonstrate that decreases in catalog orders are occurring precisely in those plants that invest in certain kinds of new IT equipment, as H4 would predict. An unexpected and problematic result in Table 4 is the negative and significant coefficient on the introduction of flexible manufacturing systems.

Hypothesis $\mathrm{H} 4$ concerns other ways that a trend in customization would reveal itself in this industry. According to $\mathrm{H} 4$, if a strategy of greater customization is becoming more profitable in this industry, then this strategy should increase the firm's probability of surviving in the valve industry. Our survey only identifies plants still in existence as of 2002 and does not measure exit and entry in this industry. To test hypothesis H4, we use data on a broader sample of valve industry plants available in the Census Bureau's Longitudinal Research Database (LRD). As discussed in Section III that describes the data for this study, the LRD data are available only through 1997, so we therefore examine entry and exit of plants between the time of the 1992 and

\footnotetext{
32 3D-CAD is design equipment and so is not manufacturing machinery. It is possible that this design software could have indirect effects on production times analyzed previously in Table 4 if plants use 3D-CAD to design the same valve in a way that is easier to setup or run. When we add a variable for the adoption of 3D-CAD between 1997 and 2002 to the Table 4 regressions, we find no significant effect of this technology on production times.
} 
1997 surveys. The LRD data cover more plants than our survey, even after adjusting for the response rate to our survey, because the LRD does not impose the sample restriction of employment greater than twenty workers. The sample of plants in the LRD for this time period for the four relevant four-digit SIC classifications is approximately 1500 plants.

Because we are analyzing a larger sample of plants than the sample from our own valve industry survey, we use the measure of customization available from the LRD - the Primary Product Specialization Ratio (PPSR). The PPSR is more correctly described as a measure of plant "specialization." It is the fraction of plant output accounted for by the plant's primary seven-digit SIC product. A higher PPSR therefore means the plant is specializing in a specific 7digit product. While the PPSR measure differs from the percent catalog measure of customization from our own survey, we expect that an increase in product customization would also imply an increase in specialization.

While we do not have data from our own survey for the over 1500 plants that report data in the LRD, suggestive evidence from our smaller sample of valve plants that we have matched to the LRD data indicates that higher values of PPSR do imply more customized production. As we note in Section III in the data description, very few plants report a "percent catalog" value for 1997 - the last year for which the LRD is available. However, we do have data on the typical batch size of products that the plant produced in 1997. While managers noted that the BATCH variable also measures the extent to which a plant engages in just-in-time production even for non-custom products, BATCH also appears to capture some differences in customization - in data for 2002 in our sample of 212 plants, the correlation between our survey's measure of customization (percent catalog) and batch size is a significant 0.15. When we examine the relationship between 1997 data on PPSR from the LRD and 1997 data on BATCH from our survey, we find a negative correlation (-0.21), significant at the .05-level. That is, more "specialized" plants that concentrate production within one 7-digit product classification are plants that produce in smaller batches and presumably also have a smaller catalog use.

Table 6 reports estimates from models that express exit from and entry into the industry between 1992 and 1997 as a function of the plant's PPSR. These results show that new entrants to the valve industry are more likely to be specialized (high PPSR) producers. These results are unchanged if we control for differences in plant size, or in value added and capital intensity (columns 1 through 3 ). Table 6 also shows that the probability that a firm will exit the valve 
industry falls with specialization. Specialization increases the survival probability of a plant. That is, plants that existed in 1992 but were no longer in operation in 1997 were less likely to be specialists. However, this result only holds for plants larger than 50 workers, and is strongest for plants larger than 100 employees (columns 4 through 6). PPSR has no effect on plant closing probabilities among the smallest valve plants.

Thus, according to patterns of entry and exit in the LRD Census of Manufacturers, the U.S. valve-making industry, like other U.S. manufacturing industries, has been shifting towards plants that are specializing in a narrower range of 7 -digit product classes. ${ }^{33}$ Given the correlations between the PPSR specialization measure and the available measures of product customization in our own survey, the valve plants that specialize are also more likely to produce more customized products using greater levels of new information technologies.

\section{The Relationships of IT to New HRM Practices and the Skills of Operators}

A number of studies argue that the introduction of new computer technologies into the workplace has caused employers to adopt new forms of work organization and HRM practices and to increase their demand for more skilled workers. This section explores those connections.

\section{IT and HRM Practices}

While the role of HRM practices is not incorporated explicitly in our model, a number of studies (Bresnahan, Brynjolfsson and Hitt, 2002; Black and Lynch, 2001; Bresnahan and Greenstein, 1997; and Mendelson, 2000) find a link between the adoption of new computer technologies and the adoption of new types of work practices. Table 7 analyzes the relationship between the adoption of IT and HRM practices in the valve-manufacturing industry during the 1997-2002 time period. We study the adoption of three HRM practices: Training (technical or basic), Teams, and Information Sharing (formal meetings). In columns (1) and (2), the dependent variable equals one for "New HRM Index" - if the plant introduced at least one of these three HRM practices; and in columns (3) and (4), the dependent variable equals one for "High New

\footnotetext{
${ }^{33} \mathrm{We}$ also analyzed the relationships between the IT measures from our survey and value added measures available in the LRD surveys. The results from these value-added models are not particularly illuminating as one might predict from the section III model. The impact of IT on value-added is likely to be ambiguous because a decline in the price of IT and a move to more customized products implies several changes that impact value added measures in offsetting ways. Customized products should sell at higher prices than commodities which would increase value added, but quantities produced could go down and costs rise more, thereby reducing value added. We report and discuss these results in Bartel, Ichniowski, and Shaw (2004).
} 
HRM Index" if the plant introduced at least two of the three practices. We include two comparable measures of IT adoption in these models: "New IT Index" equals one if the plant introduced at least one of the following: New CNC machine, flexible manufacturing systems (FMS), or automated inspection sensors; and "High New IT Index" equals one if the plant introduced at least two of these forms of IT.

The results in Table 7 show a positive and significant correlation between the adoption of IT and HRM. A plant that introduced at least one form of new IT between 1997 and 2002 was significantly more likely to introduce at least one new HRM practice during this time period. ${ }^{34}$ High IT adopters are also more likely to be High HRM adopters.

$\underline{\text { IT and Operators' Skill Requirements }}$

A large literature examines the relationship between changes in workforce skills and the introduction of new information technologies. Industry-level studies typically measure skill by the percentage of workers (or labor costs) in an industry that are non-production or white collar workers. These studies measure technology by expenditures on computing equipment or estimates of the computer capital stock for the industry. ${ }^{35}$ Several establishment-level studies also exist (Dunne and Schmitz, 1995; Doms, Dunne and Troske, 1997) that examine the relationship between IT and demand for skilled workers. While these studies use detailed measures of technology such as the use of computer-automated design or flexible manufacturing cells and networks, they measure worker skill by the share of production workers in the plant's labor force or education level of the plant's workers. The conclusion from these studies is that there is a positive correlation between the use of advanced technologies and the worker skill level in the establishment, but this relationship is generally not evident in longitudinal analyses.

The detailed data in our survey enable us to address a somewhat different question than previous studies. Not only does the survey provide detailed plant-specific data on specific types of IT equipment, but the data on worker skills pertain to employees within a given occupation all of whom have comparable education levels. Therefore, the analysis here examines whether skill requirements change within a narrowly defined occupational group of workers - machine operators - after the introduction of IT and not whether an industry or plant workforce now has a

\footnotetext{
${ }^{34} \mathrm{We}$ also find that plants that adopted at least one form of new IT between 1997 and 2002 are more likely to report using vendor-provided training for their machine operators in 2002.

${ }^{35}$ As examples, Berman, Bound and Griliches (1994), Berndt, Morrison and Rosenblum (1994), and Autor, Katz and Krueger (1998) find a positive correlation between increases in computer investment and increases in the share of skilled labor within an industry.
} 
larger proportion of white-collar employees. In our sample of valve plants, the educational requirement for machine operators is primarily a high school diploma (71\%) or some high school (9\%). Only $4 \%$ of the plants required a certificate from a technical school and $5 \%$ required an apprenticeship. Nine percent of the plants had no educational requirement for their operators.

In Table 8, we present regressions in which the dependent variable equals one if the plant reported that a particular skill's importance increased between 1997 and 2002. We collected data on six types of skills: math skills, computer skills, skills for programming machine operations, problem-solving skills, cutting tool knowledge, and skills in running multiple machines. The survey asked respondents if a skill had increased in importance, decreased in importance or stayed the same between 1997 and 2002. The bottom row of Table 8 reports the means for these variables and shows that for each skill at least half of the respondents reported an increase in importance. ${ }^{36}$ The same two measures of IT adoption used in the Table 7 analysis are included in the Table 8 regressions - New IT Index and High New IT Index. The first set of regression results (row 1 of Table 8) shows that New IT is positively correlated with increases in the demand for computer skills, programming skills and cutting tool knowledge at the .01-level and the correlation between IT and the demand for problem-solving skills is significant at the .10level. When the High New IT variable is added to these regressions (row 2), it is clear that plants with High New IT are plants that experience an especially large increase in the demand for computer skills among operators. These findings indicate that adopting new IT has important implications for the composition of skills required of high-school-educated machine operators.

\section{Conclusion}

The central proposition of this study is that new information technologies adopted in the 1990s changed the competitive strategy of manufacturing firms. Firms in the U.S. increasingly shifted to the production of customized products, and this shift in strategy occurred because the falling cost of information technologies produced productivity gains, especially faster machine setup times, that favored the production of customized products instead of commodities. Theorists have previously made this point but data have been lacking to test the proposition. Most empirical researchers investigating the returns to IT investments have focused on gains in

\footnotetext{
${ }^{36}$ The corresponding values for decreased in importance are: Math: 0.16; Computers: 0.02; Programming: 0.07; Problem-Solving: 0.07; Cutting Tool Knowledge: 0.12; and Operating Multiple Machines: 0.02.
} 
certain measures of productivity, though well aware that they are likely to be underestimating the total returns to IT investments. Testing this proposition requires the collection of unique data data that identifies what IT really means in the context of the production process, data on the productivity gains from IT at the process level, and data on product customization.

Unique data on specific IT investments, productivity measures, work practices, and worker skills from valve-making plants map out a very clear pattern of findings that is consistent with the study's main proposition and that pinpoints some of the detailed mechanisms that permit this change in business strategy. In the valve-making industry, new computerized technologies raise productivity by lowering the time it takes to setup the production line for new product runs, and also lowering the runtime and the inspection time during production. We also document that IT adopters increase the customization of their products, and the efficiency gains due to new IT investments help explain this change in business strategy - lower setup time increases the efficiency and lowers the cost of customized production in short batch production runs. Plants that adopt new IT experience an even broader set of organizational changes since they are also more likely to adopt new work practices and require different skills from their operators. In sum, the falling price of an input - the price of computerized capital - changes not only the quantity of that input and related inputs, but it also changes a business's competitive strategy as well as the work practices and skill requirements of the workforce needed to implement the new strategy. Once a business invests in new IT-based production machinery and installs the equipment on the factory floor, it will be changing the fundamental nature of what it does and how it does it. 


\section{References}

Athey, Susan and Scott Stern (2002). "The Impact of Information Technology and Job Design on Emergency Health Care Outcomes," RAND Journal of Economics, Vol. 33, No. 3, pp. 399-432.

Autor, David, Lawrence Katz and Alan Krueger (1998). "Computing Inequality: Have Computers Changed the Labor Market?" Quarterly Journal of Economics, vol. 113, pp.11691214.

Autor, David, Frank Levy and Richard Murnane (2003). "The Skill Content of Recent Technological Change: An Empirical Exploration, Quarterly Journal of Economics, vol 118, no. 4, pp. 1279-1333.

Autor, David, Lawrence Katz and Melissa Kearny (2005). "Trends in U.S. Wage Inequality: ReAssessing the Revisionists", NBER Working Paper No. 11627, September.

Bartel, Ann, Casey Ichniowski and Kathryn Shaw (2004) "Using "Insider Econometrics" to Study Productivity, “American Economic Review, vol. 94, no. 2, pp. 217-222.

Berman, Eli, John Bound and Zvi Griliches (1994). "Changes in the Demand for Skilled Labor Within U.S. Manufacturing Industries: Evidence from the Annual Survey of Manufacturing," Quarterly Journal of Economics, vol. 109, pp. 367-397.

Berndt, Ernst, Catherine Morrison, and Larry Rosenblum (1994). "High-Tech Capital Formation and Labor Composition in U.S. Manufacturing Industries: An Exploratory Analysis," Journal of Econometrics, vol.65, no. 1, pp. 9-43.

Black, Sandra and Lisa M. Lynch (2001). "How to Compete: The Impact of Workplace Practices and Information Technology on Productivity," Review of Economics and Statistics, 83(3), 434445.

Bresnahan, Timothy and Manuel Trajtenberg (1995) "General Purpose Technologies - Engines of Growth." Journal of Econometrics, vol 65, no. 1, pp. 83-108.

Bresnahan, Timothy F. and Shane Greenstein (1996). "Technical Progress in Computing and in the Uses of Computers," Brookings Papers on Economic Activity, Microeconomics, pp. 1-83.

Bresnahan, Timothy F. and S. Greenstein (2001). "The Economic Contribution of Information Technology: Towards Comparative and User Studies," Journal of Evolutionary Economics, vol. 11, pp.95-118.

Bresnahan, Timothy, Erik Brynjolfsson, and Loren Hitt (2002). "Information Technology, Work Organization, and the Demand for Skill Labor: Firm-Level Evidence." Quarterly Journal of Economics, vol. 14, no. 4, pp. 23-48.

Brynjolfsson, Erik and Lorin Hitt (2003). "Computing Productivity: Firm-level Evidence", Review of Economics and Statistics, Vol. 85, No. 4, pp. 793-808. 
Brynjolfsson, Erik, Michael D. Smith, and Yu (Jeffrey) Hu (2003). "Consumer Surplus in the Digital Economy: Estimating the Value of Increased Product Variety at Online Booksellers" Management Science, Vol. 49, No. 11, pp. 1580-1596.

Da Silveira G., D. Borenstein, F.S. Fogliatto (2001). "Mass Customization: Literature Review and Research Directions." International Journal of Production Economics. 72: 1-13.

David, Paul, "Technology Diffusion, Public Policy, and Industrial Competitiveness" (1986). In R. Landau and N. Rosenberg, eds., The Positive Sum Strategy: Harnessing Technology for Economic Growth. Washington, DC: National Academy Press.

Doms, Mark, Timothy Dunne and Kenneth R. Troske. (1997) "Workers, Wages and Technology," Quarterly Journal of Economics. vol. 112, no.1, pp. 253-290.

Dunne, Timothy and James Schmitz (1995). "Wages, Employment Structure and Employer SizeWage Premia: Their Relationship to Advanced-Technology Usage at U.S. Manufacturing Establishments," Economica, vol. 62, pp. 89-107.

Gabor, Andrea, "Running a Hospital Like a Factory, in a Good Way," The New York Times, February 22, 2004.

Heckman, James (1990), "Varieties of Selection Bias," American Economic Review, vol. 80, no. 2, pp. 313-318.

Heckman, James, Robert Lalonde and James Smith (1999), "The Economics and Econometrics of Active Labor Market Policies," in The Handbook of Labor Economics, eds. Orley Ashenfelter and David Card, Amsterdam: North Holland.

Hubbard, Thomas N. (2003) "Information, Decisions and Productivity: On-Board Computers and Capacity Utilization in Trucking," American Economic Review, vol 93, no. 4, pp. 13281353.

Jorgenson, Dale W., Mun C. Ho and Kevin Stiroh (2003) "Growth of U.S. Industries and Investments in Information Technology and Higher Education," in NBER/CRIW Conference on Measurement of Capital in the New Economy.

Karshenas, Massoud and Paul Stoneman (1993). "Rank, Stock, Order and Epidemic Effects in the Diffusion of New Process Technologies: An Empirical Model," Rand Journal of Economics Vol. 24, No. 4, pp. 503-528.

Mendelson, Haim (2000). "Organizational Architecture and Success in the Information Technology Industry,” Management Science, Vol. 46, No.4, pp. 513-529.

Milgrom, Paul and John Roberts (1990) "The Economics of Modern Manufacturing: Technology, Strategy and Organization" American Economic Review, vol. 80, no. 3, pp. 511528. 
Oliner, Stephen D. and Daniel E. Sichel (2000). "The Resurgence of Growth in the Late 1990s: Is Information Technology the Story?" Journal of Economic Perspectives, vol. 14, no. 4, pp. 322.

Pardakturk, Ali and Haim Mendelson (2004). “Competitive Customization,” Stanford Working Paper, October.

Rose, Nancy and Paul Joskow (1990) "The Diffusion of New Technologies: Evidence from the Electric utility Industry," Rand Journal of Economics, Vol. 21, pp.354-373.

Stoneman, P (1983). The Economics of Technological Change. Oxford: Oxford University Press. 
Figure 1

Valve Products

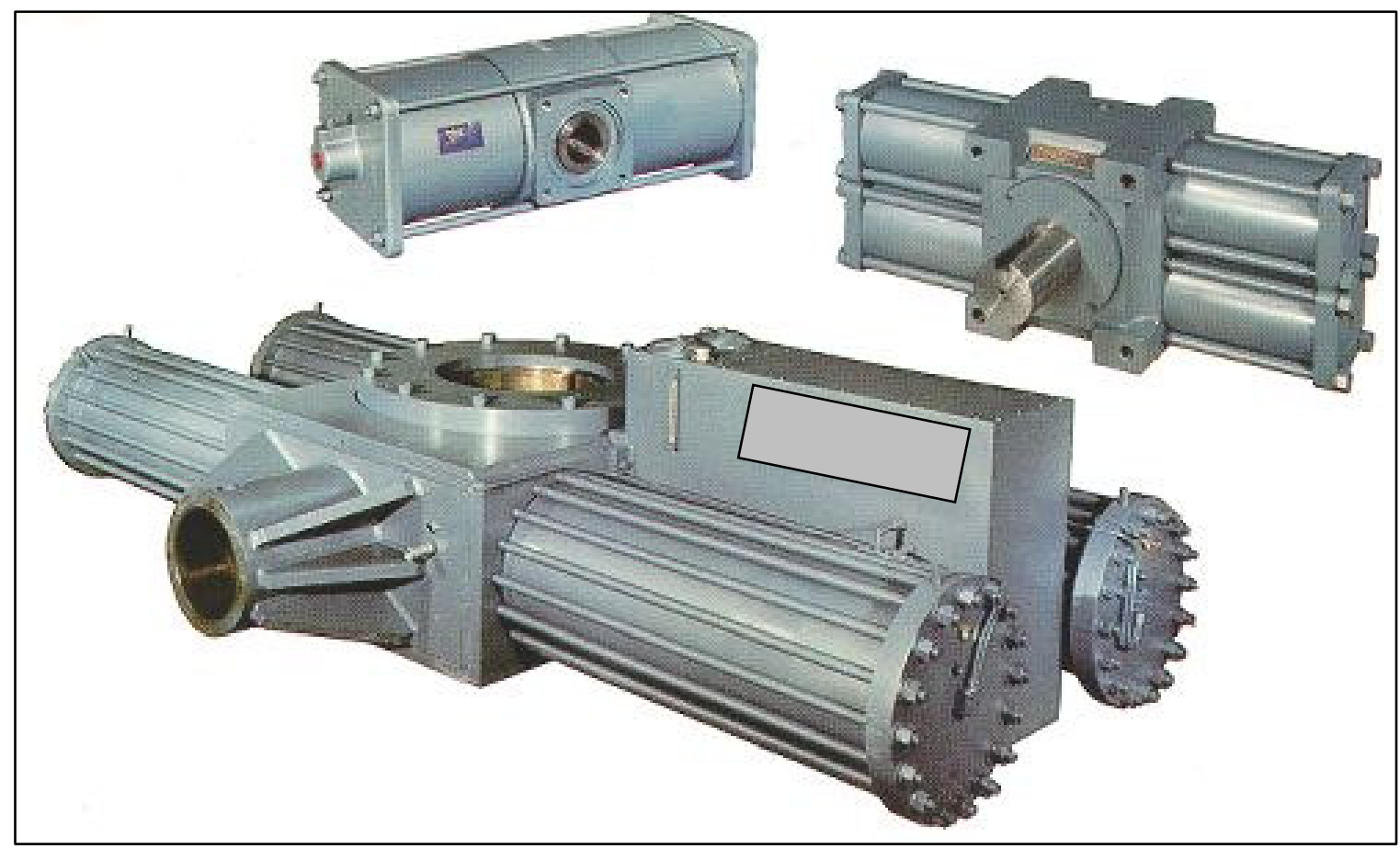


Figure 2

CNC Machine (Circa Late 1980s)

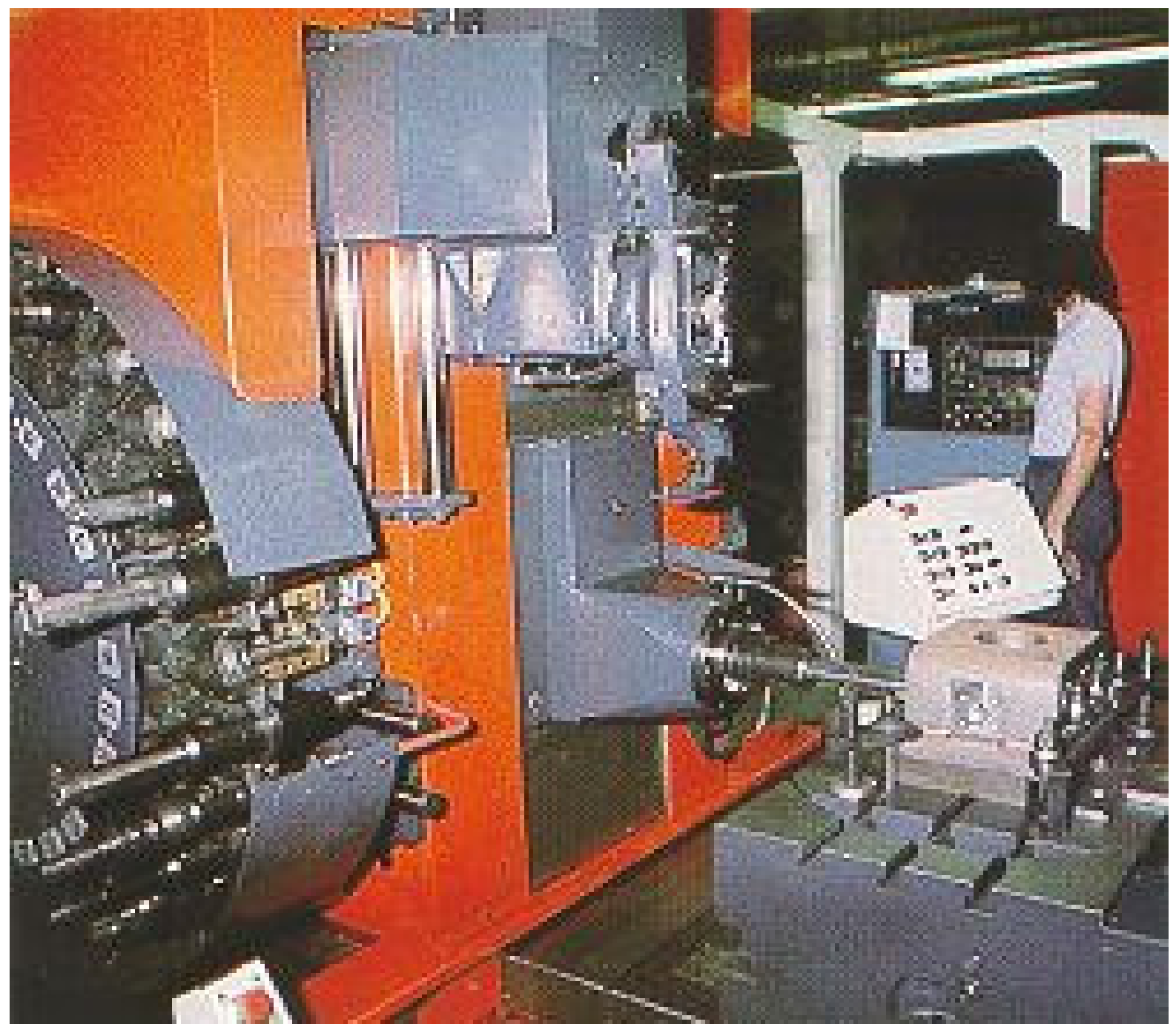




\section{Figure 3}

\section{Modern-Day CNC Technology}

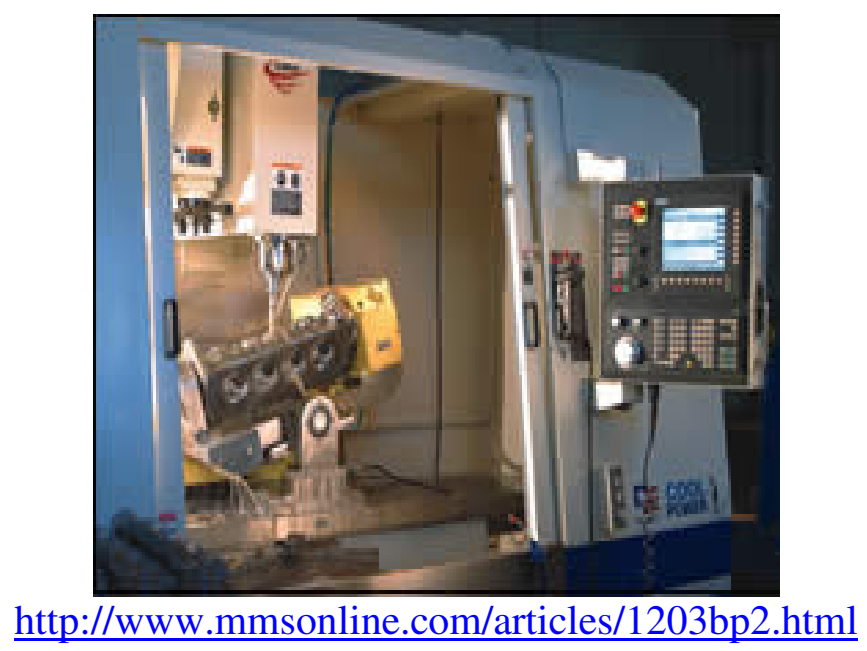

CNC ported cylinder heads are produced on multi-axis machining centers using the Siemens Sinumerik $840 \mathrm{D}$ controller (which is a modern controller). The part being machined is visible.

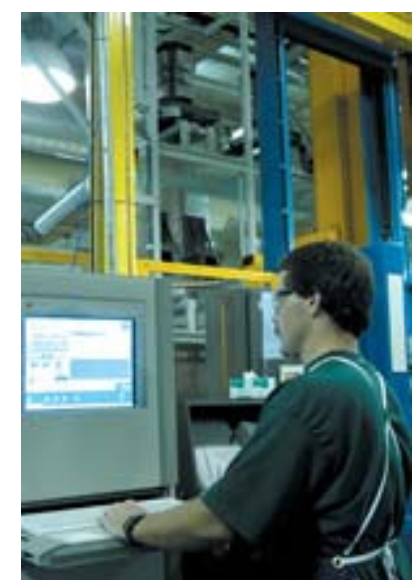

http://www.mmsonline.com/articles/070101.html

Cell controller, which operates three horizontal machining centers and a multi-pallet storage system, as a central CNC for the entire cell. Moreover, the cell controller is pivotal to managing the shop's manufacturing because of its ability to act as a central data collection point for all of the machining center's production. 
Figure 3 (Continued)

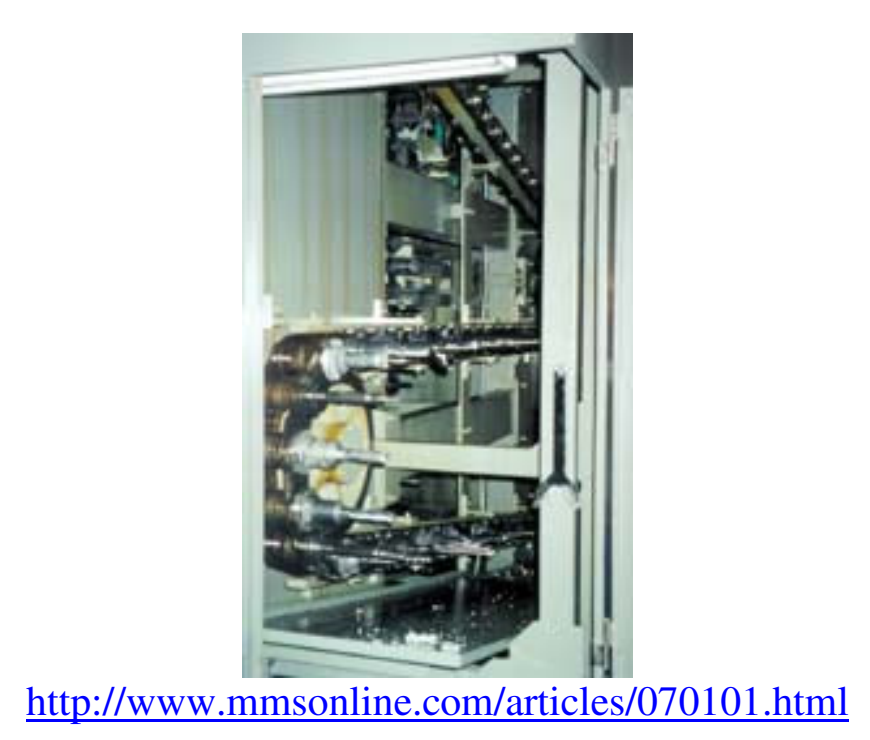

Cutting tools are selected and loaded in accordance with the production schedule. Two of the machining centers carry 240 tools each, and the third has capacity for 120. 


\section{Figure 4}

\section{Proportion of Plants with Computer-Aided Production Technologies}

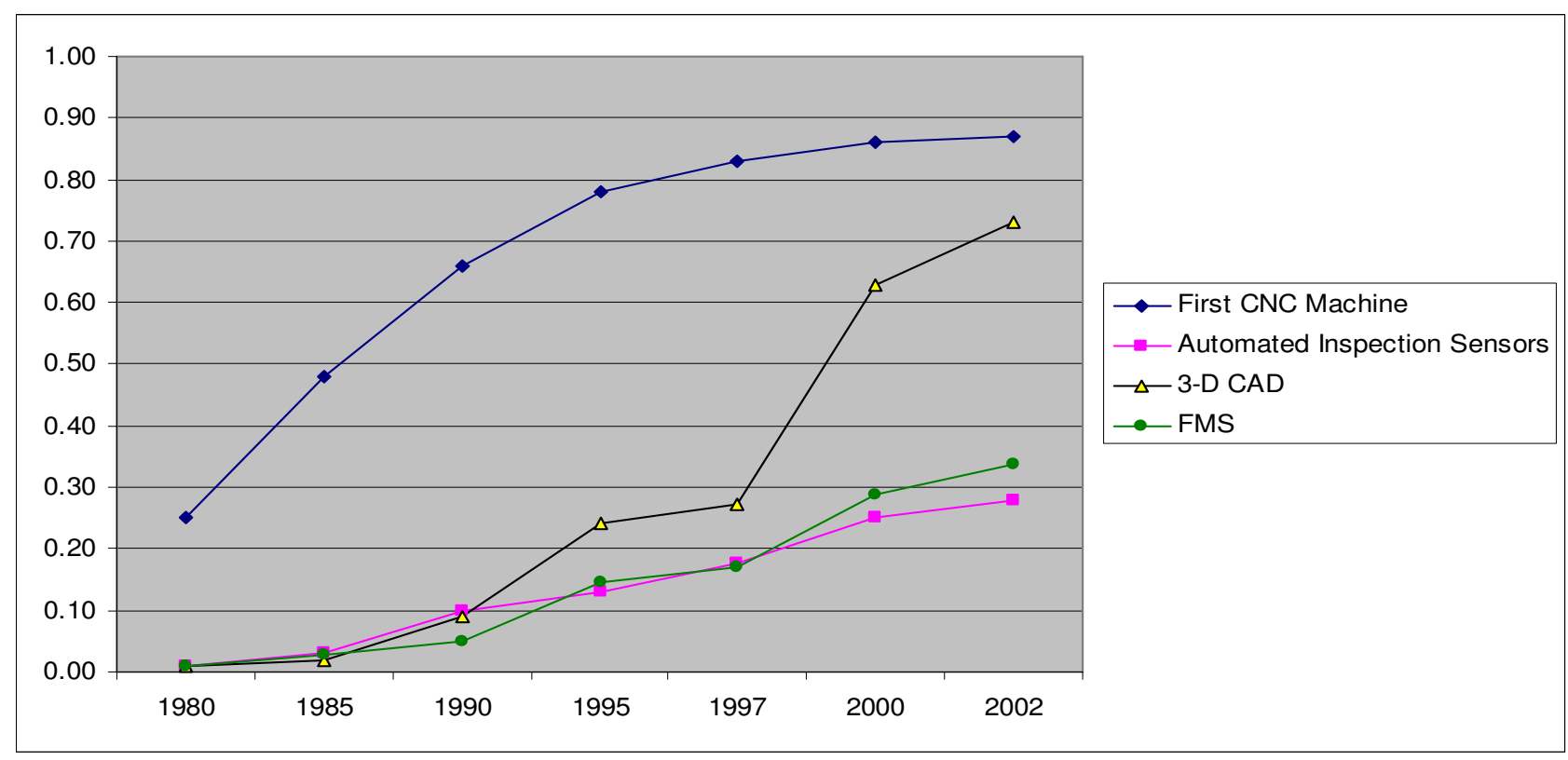

Data source: Personal survey of 212 valve making plants.

Figure 5

Proportion of Plants Adopting IT, 1997-2002

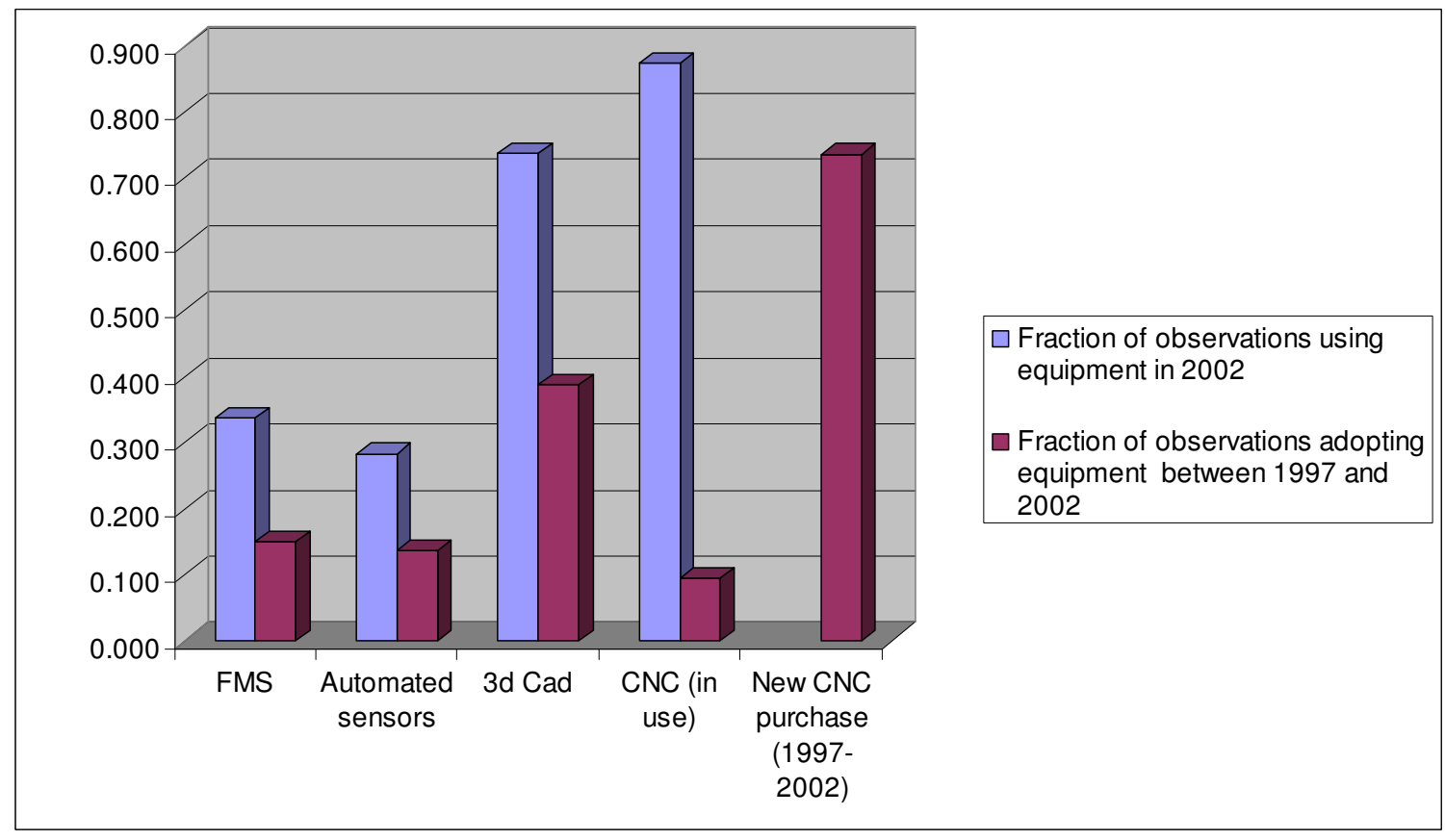

Data source: Personal survey of 212 valve-making plants. 
Figure 6

Comparison of 1997 and 2002 Production Times for a Given Product (Median Number of Hours for Each Stage of Production)

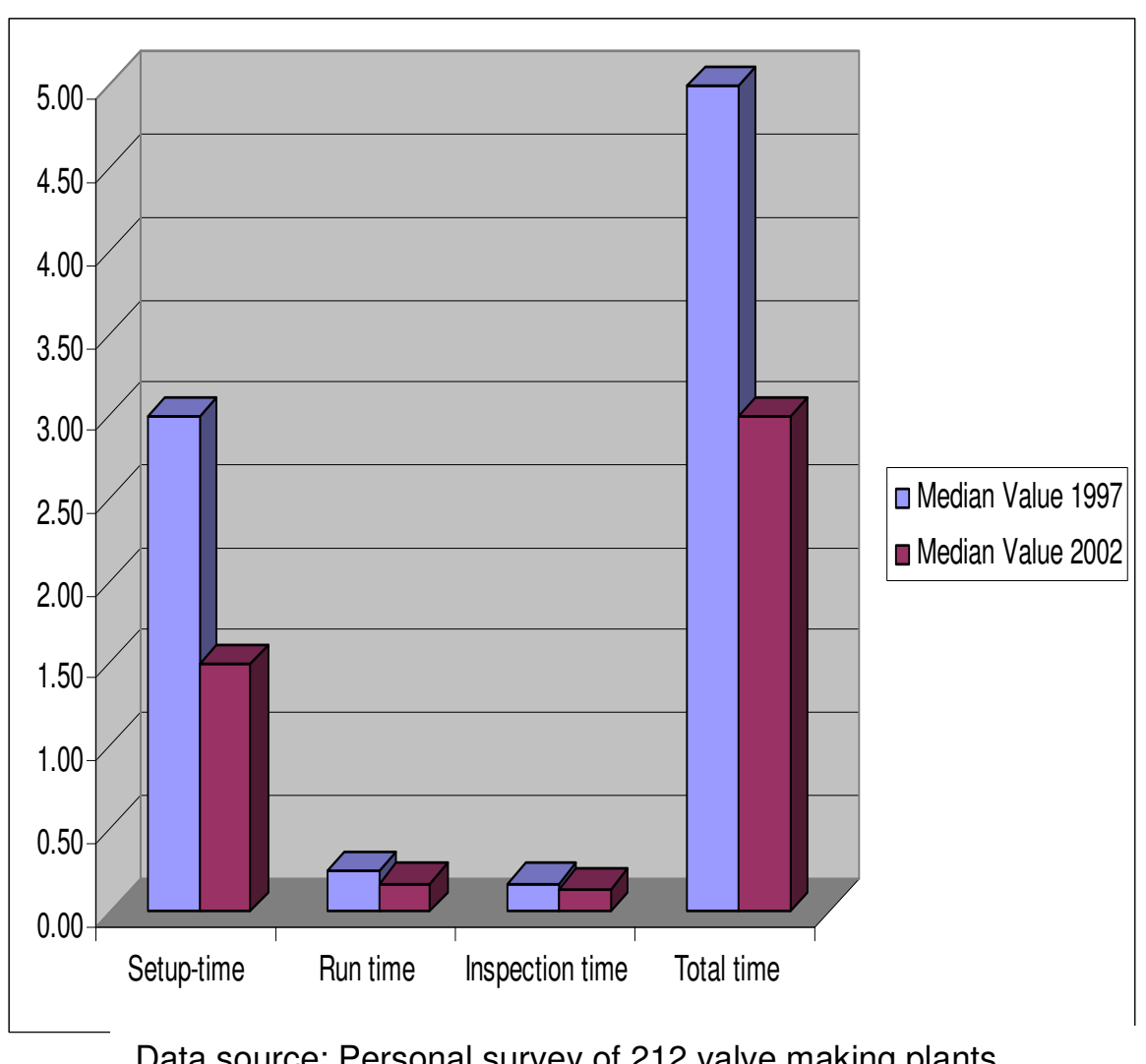

Data source: Personal survey of 212 valve making plants. 
Figure 7

Proportion of Plants with New HRM Practices

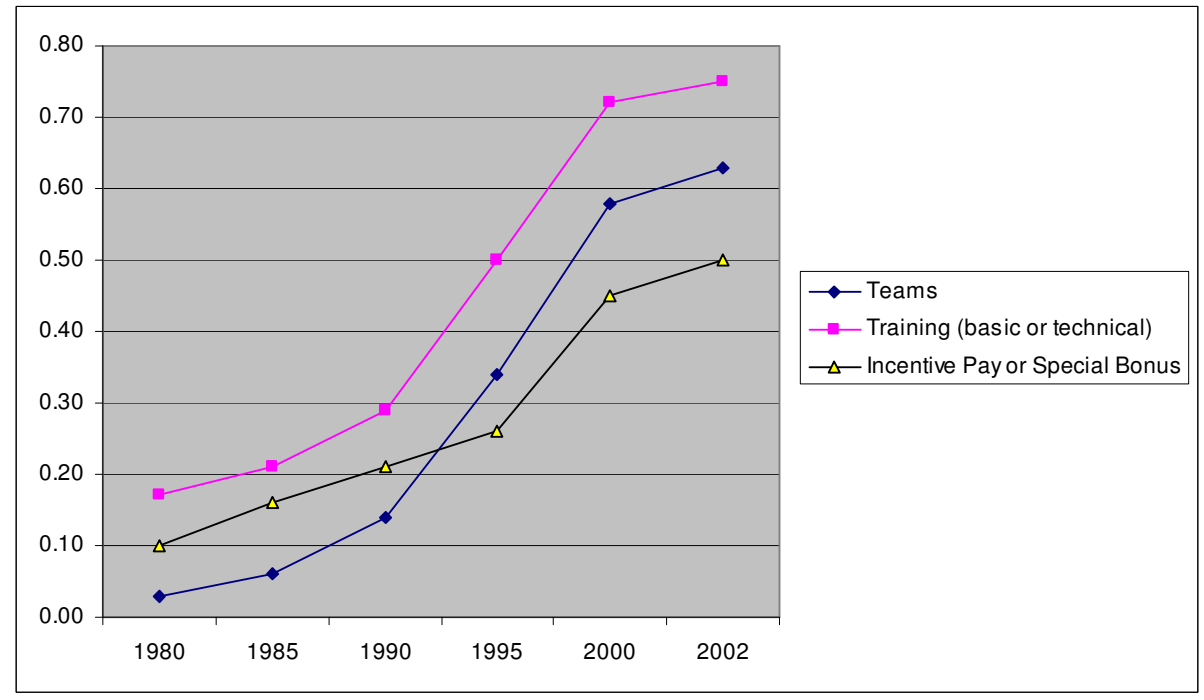

Data source: Personal survey of 212 valve making plants.

Figure 8

Proportion of Plants Adopting New HR Practices, 1997-2002

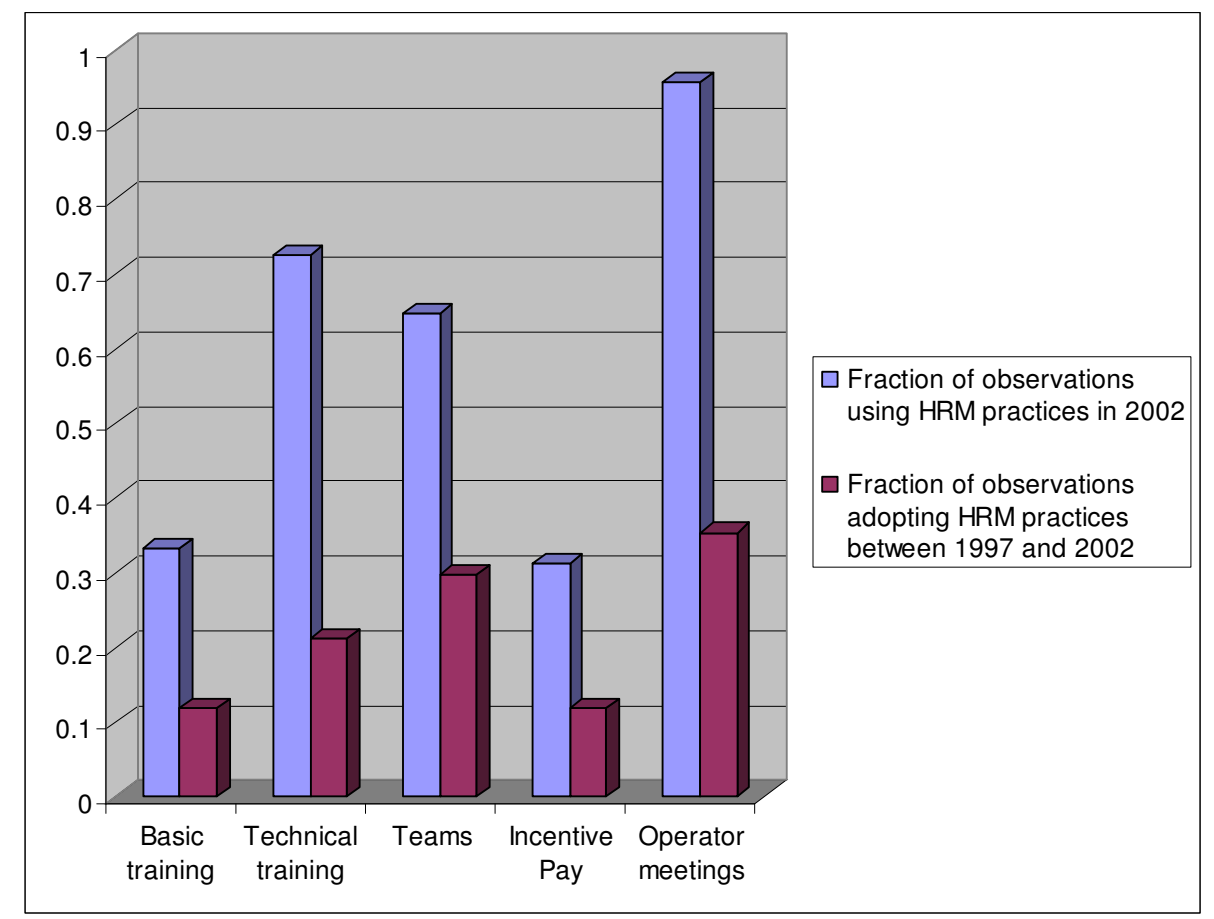

Data source: Personal survey of 212 valve making plants. 
Table 1

Econometric Case Study: The Effects of IT on Production Efficiency within One Plant

\begin{tabular}{|c|c|c|c|c|c|c|c|}
\hline $\begin{array}{c}\text { Dependent } \\
\text { Variable }\end{array}$ & $\begin{array}{c}\text { Means } \\
\text { (s.d.) }\end{array}$ & $\underset{\text { time })^{\mathrm{a}}}{\log (\text { Setup }}$ & $\begin{array}{c}\log (\text { Setup } \\
\text { time) }{ }^{\mathrm{a}}\end{array}$ & Setup time & $\begin{array}{c}\text { Log } \\
\text { (Runtime) }\end{array}$ & $\begin{array}{c}\text { Log } \\
\text { (Runtime) }\end{array}$ & Runtime \\
\hline $\begin{array}{l}\log (“ C N C \\
\text { Quality”) }\end{array}$ & $\begin{array}{c}1.72 \\
(0.48)\end{array}$ & $\begin{array}{c}-0.876 * * * * \\
(0.048)\end{array}$ & $\begin{array}{c}-0.903 * * * \\
(0.051)\end{array}$ & & $\begin{array}{c}-0.602 * * * \\
(0.046)\end{array}$ & $\begin{array}{c}-0.632 * * * \\
(0.048)\end{array}$ & \\
\hline "CNC Quality" & $\begin{array}{l}6.07 \\
(2.87)\end{array}$ & & & $\begin{array}{c}-55.69 * * * \\
(3.24)\end{array}$ & & & $\begin{array}{c}-8.70 * * * \\
(2.47)\end{array}$ \\
\hline Year & $\begin{array}{c}1998 \\
(6)\end{array}$ & & $\begin{array}{c}0.005 \\
(0.003)\end{array}$ & & & $\begin{array}{c}0.003 \\
(0.003)\end{array}$ & \\
\hline $\begin{array}{l}\mathbf{R}^{2} \text { - within } \\
\text { between } \\
\text { overall } \\
\mathbf{N}\end{array}$ & & $\begin{array}{l}0.42 \\
0.68 \\
0.60 \\
790 \\
\end{array}$ & $\begin{array}{l}0.43 \\
0.68 \\
0.61 \\
762 \\
\end{array}$ & $\begin{array}{l}0.39 \\
0.49 \\
0.44 \\
790 \\
\end{array}$ & $\begin{array}{l}0.27 \\
0.57 \\
0.48 \\
790 \\
\end{array}$ & $\begin{array}{l}0.29 \\
0.56 \\
0.49 \\
762 \\
\end{array}$ & $\begin{array}{l}0.03 \\
0.21 \\
0.17 \\
790 \\
\end{array}$ \\
\hline $\begin{array}{l}\text { Mean } \\
\text { (s.d.) } \\
\text { Median }\end{array}$ & & $\begin{array}{c}6.15 \\
(0.81) \\
6.20\end{array}$ & & $\begin{array}{c}623.2 \\
(507.9) \\
495 \\
\end{array}$ & $\begin{array}{c}3.93 \\
(1.43) \\
3.82 \\
\end{array}$ & & $\begin{array}{c}750.6 \\
(325.7) \\
46 \\
\end{array}$ \\
\hline
\end{tabular}

Note: Fixed effects regression for product; standard errors in parentheses.

*** Significant at the $1 \%$ level. Number of products $=331$

When the dependent variable is $\log$ (setup time), setup time is measured for each of the 331 products, for $\mathrm{t}=1$ to 3 time periods for one plant. The $\log$ (runtime) is measured comparably for product $\mathrm{i}$ and time t. "CNC quality" is the number of $\mathrm{CNC}$ machines used to produce that product $i$ at each time $t$. 
Table 2

The Diffusion of New Technologies and New HRM Practices in the U.S. Valve Industry

\begin{tabular}{|c|c|c|c|c|}
\hline \multicolumn{5}{|c|}{ Panel A: Percent of Plants with Computer-Aided Production Technologies } \\
\hline Year & $\begin{array}{c}\text { First CNC } \\
\text { Machine }\end{array}$ & $\begin{array}{c}\text { Automated } \\
\text { Inspection Sensors }\end{array}$ & $\begin{array}{c}\text { Flexible } \\
\text { Manufacturing Systems }\end{array}$ & $\begin{array}{c}\text { 3-D } \\
\text { Computer-Aided } \\
\text { Design }\end{array}$ \\
\hline 1980 & 0.25 & 0.01 & 0.02 & 0.01 \\
1985 & 0.48 & 0.03 & 0.04 & 0.02 \\
1990 & 0.66 & 0.10 & 0.06 & 0.09 \\
1995 & 0.78 & 0.13 & 0.16 & 0.24 \\
2000 & 0.86 & 0.25 & 0.31 & 0.63 \\
2002 & 0.87 & 0.28 & 0.33 & 0.73 \\
\hline
\end{tabular}

\begin{tabular}{|c|c|c|c|}
\hline \multicolumn{5}{|c|}{ Panel B: Percent of Plants with New HRM Practices } \\
\hline Year & Teams & $\begin{array}{c}\text { Training } \\
\text { (basic or technical) }\end{array}$ & $\begin{array}{c}\text { Incentive Pay or } \\
\text { Special Bonus }\end{array}$ \\
\hline 1980 & .03 & .17 & .10 \\
1985 & .06 & .21 & .16 \\
1990 & .14 & .29 & .21 \\
1995 & .34 & .50 & .26 \\
2000 & .58 & .72 & .45 \\
2002 & .63 & .75 & .50 \\
\hline
\end{tabular}


Table 3

Summary Statistics on Production Efficiency, Product Customization, New Computer-Based Production Technologies, and HRM Practices

\begin{tabular}{|c|c|c|c|c|c|}
\hline \multicolumn{2}{|l|}{$\begin{array}{l}\text { Panel A: Information Technology } \\
\text { and HR Practices }\end{array}$} & \multicolumn{3}{|c|}{$\begin{array}{c}\text { Fraction of obs. using } \\
\text { equipment or HRM } \\
\text { practices in } 2002\end{array}$} & \multirow{2}{*}{$\begin{array}{c}\begin{array}{c}\text { Fraction of obs. } \\
\text { adopting equipment } \\
\text { or HRM practices } \\
\text { bet. } 1997 \text { and } 2002\end{array} \\
\\
0.151\end{array}$} \\
\hline FMS & & \multicolumn{3}{|c|}{0.337} & \\
\hline Automated sensors & & \multicolumn{3}{|c|}{0.283} & 0.137 \\
\hline $3 d \mathrm{Cad}$ & & \multirow{2}{*}{\multicolumn{3}{|c|}{$\begin{array}{l}0.738 \\
0.873\end{array}$}} & 0.387 \\
\hline CNC (in use) & & & & & 0.095 \\
\hline New CNC purchase (1997-2002) & & \multicolumn{3}{|c|}{$\begin{array}{c}0.873 \\
-\end{array}$} & 0.736 \\
\hline Basic training & & \multicolumn{3}{|c|}{0.333} & 0.119 \\
\hline Technical training & & \multicolumn{3}{|c|}{0.726} & 0.211 \\
\hline Teams & & \multicolumn{3}{|c|}{0.647} & 0.298 \\
\hline Incentive Pay & & \multirow{2}{*}{\multicolumn{3}{|c|}{$\begin{array}{l}0.312 \\
0.957\end{array}$}} & 0.118 \\
\hline Operator meetings & & & & & 0.354 \\
\hline $\begin{array}{l}\text { Panel B: Product-Level } \\
\text { Information Technology } \\
\text { Measure }\end{array}$ & $\begin{array}{l}\text { Median } \\
\text { Value } \\
1997^{1}\end{array}$ & $\begin{array}{l}\text { Median } \\
\text { Value } \\
2002^{2}\end{array}$ & $\begin{array}{l}\text { Mean } \\
\text { Value } \\
1997^{1}\end{array}$ & $\begin{array}{l}\text { Mean } \\
\text { Value } \\
2002^{2}\end{array}$ & $\begin{array}{l}\text { Log change between } \\
1997 \text { and } 2002\end{array}$ \\
\hline $\begin{array}{l}\text { Number of CNC Machines Plant } \\
\text { Uses to Produce Its Main Product }\end{array}$ & 6 & 5 & 5.63 & 4.97 & -0.189 \\
\hline \multirow{2}{*}{$\begin{array}{l}\text { Panel C: Product-Level } \\
\text { Production Efficiency } \\
\text { Measures }\end{array}$} & $\begin{array}{l}\text { Median } \\
\text { Value }\end{array}$ & $\begin{array}{c}\text { Median } \\
\text { Value }\end{array}$ & $\begin{array}{l}\text { Mean } \\
\text { Value }\end{array}$ & $\begin{array}{l}\text { Mean } \\
\text { Value }\end{array}$ & \multirow{2}{*}{$\begin{array}{l}\text { Log change between } \\
1997 \text { and } 2002\end{array}$} \\
\hline & $1997^{1}$ & $2002^{2}$ & $1997^{1}$ & $2002^{2}$ & \\
\hline Setup time & 3.00 & 1.50 & 11.03 & 6.04 & -0.681 \\
\hline Run time & 0.25 & 0.17 & 10.77 & 9.32 & -0.371 \\
\hline Inspection time & 0.17 & 0.14 & 1.22 & 0.84 & -0.334 \\
\hline Total time & 5.00 & 3.00 & 24.08 & 16.59 & -0.488 \\
\hline \multirow{2}{*}{$\begin{array}{l}\text { Panel D: Product } \\
\text { Customization Measures }\end{array}$} & $\begin{array}{l}\text { Median } \\
\text { Value }\end{array}$ & $\begin{array}{l}\text { Median } \\
\text { Value }\end{array}$ & $\begin{array}{l}\text { Mean } \\
\text { Value }\end{array}$ & $\begin{array}{l}\text { Mean } \\
\text { Value }\end{array}$ & \multirow{2}{*}{$\begin{array}{l}\text { Log change between } \\
1997 \text { and } 2002\end{array}$} \\
\hline & 1997 & 2002 & 1997 & 2002 & \\
\hline Percent Catalog $(N=70)$ & 70 & 70 & 62.31 & 57.52 & -0.057 \\
\hline $\begin{array}{l}\text { Percent Catalog Fell }(N=184) \\
\text { Percent Catalog Rose }(N=184)\end{array}$ & \multicolumn{5}{|c|}{0.25} \\
\hline Batch Size & 150 & 68 & 3152 & 2870 & -0.646 \\
\hline
\end{tabular}

1. In hours, except for Number of machines.

2. In hours, except for Number of machines. 
Table 4

The Effects of IT and HRM on Production Efficiency: ${ }^{\text {a }}$

Dependent Variables: Product-Specific Production Times

\begin{tabular}{|c|c|c|c|}
\hline $\begin{array}{l}\text { Dependent } \\
\text { Variable: }\end{array}$ & $\begin{array}{l}\text { Percentage Change in } \\
\text { Setup-Time } 97-02\end{array}$ & $\begin{array}{l}\text { Percentage Change in } \\
\text { Run Time 97-02 }\end{array}$ & $\begin{array}{l}\text { Percentage Change in } \\
\text { Inspection Time 97-02 }\end{array}$ \\
\hline $\begin{array}{c}\log \text { (“'Increase } \\
\text { CNC Quality”) } \\
97-02\end{array}$ & $\begin{array}{c}-0.777 * * * \\
(0.048)\end{array}$ & $\begin{array}{c}-0.438 * * * \\
(0.079)\end{array}$ & $\begin{array}{l}-0.139 \\
(0.265)\end{array}$ \\
\hline $\begin{array}{c}\text { Introduced } \\
\text { Flexible } \\
\text { Manuf. System } \\
97-02\end{array}$ & $\begin{array}{c}-0.184 * * * \\
(0.052)\end{array}$ & $\begin{array}{l}-0.191 * * \\
(0.089)\end{array}$ & $\begin{array}{c}.237 \\
(0.301)\end{array}$ \\
\hline $\begin{array}{c}\text { Introduced } \\
\text { Automated } \\
\text { Inspection } \\
\text { Sensors 97-02 }\end{array}$ & $\begin{array}{l}-0.043 \\
(0.060)\end{array}$ & $\begin{array}{c}0.057 \\
(0.098)\end{array}$ & $\begin{array}{c}-0.884 * * * \\
(0.341)\end{array}$ \\
\hline $\begin{array}{c}\text { Introduced } \\
\text { Technical } \\
\text { Training 97-02 }\end{array}$ & $\begin{array}{c}-0.549 * * * \\
(0.050)\end{array}$ & $\begin{array}{c}-0.308 * * * \\
(0.083)\end{array}$ & $\begin{array}{l}-0.266 \\
(0.299)\end{array}$ \\
\hline $\begin{array}{c}\text { Introduced } \\
\text { Teams } \\
97-02 \\
\end{array}$ & $\begin{array}{c}0.014 \\
(0.044)\end{array}$ & $\begin{array}{c}0.041 \\
(0.072)\end{array}$ & $\begin{array}{l}-0.417 \\
(0.262)\end{array}$ \\
\hline $\begin{array}{c}\text { Observations } \\
\text { Pseudo } \mathrm{R}^{2}\end{array}$ & $\begin{array}{l}146 \\
0.12\end{array}$ & $\begin{array}{r}140 \\
0.15\end{array}$ & $\begin{array}{l}151 \\
0.10\end{array}$ \\
\hline
\end{tabular}

Columns 1 and 2 use median regression; column 3 uses least squares. Standard errors in parentheses

$*$ significant at $10 \% ; * *$ significant at $5 \%$; *** significant at $1 \%$

${ }^{a}$ All regressions include controls for age of plants (five age dummies), number of shopfloor workers and dummy for unionization 
Table 5

The Effects of IT on Product Customization, 1997-2002 ${ }^{\mathrm{a}}$

Dependent Variable: Percent Catalog Down, 1997-2002 ${ }^{\text {b }}$

\begin{tabular}{|c|c|c|c|}
\hline $\begin{array}{c}\text { Introduced } \\
\text { 3D-CAD, 97-02 }\end{array}$ & $\begin{array}{c}0.161 * * * \\
(0.069)\end{array}$ & $\begin{array}{l}0.151 * * \\
(0.069)\end{array}$ & $\begin{array}{c}0.156^{* * * *} \\
(0.069)\end{array}$ \\
\hline $\begin{array}{c}\text { Bought New CNC } \\
\text { Machine, 97-02 }\end{array}$ & & $\begin{array}{l}0.134^{*} \\
(0.065)\end{array}$ & $\begin{array}{l}0.132 * \\
(0.061)\end{array}$ \\
\hline $\begin{array}{c}\text { Introduced Flexible } \\
\text { Manufacturing } \\
\text { System, 97-02 }\end{array}$ & & & $\begin{array}{c}-0.221 * * * \\
(0.044)\end{array}$ \\
\hline $\begin{array}{c}\text { Introduced Automated } \\
\text { Inspection Sensors, } \\
97-02\end{array}$ & & & $\begin{array}{c}-0.041 \\
(0.082)\end{array}$ \\
\hline $\mathrm{N}$ & 182 & 182 & 182 \\
\hline Pseudo R-squared & 0.11 & 0.12 & 0.18 \\
\hline
\end{tabular}

Standard errors in parentheses

*Significant at $10 \%$; ** Significant at 5\%;*** Significant at $1 \%$

${ }^{a}$ Regressions include controls for age of plants, number of shopfloor workers, and dummy for unionization

${ }^{\mathrm{b}}$ Dependent Variable is dummy variable which equals one if percent sold from catalog fell from 1997 to 2002 (mean

$=0.24)$. Regression is estimated as probit evaluated at the mean 
Table 6

Determinants of Entry and Exit in the Valve Industry Between 1992 and $1997^{\text {a }}$

\begin{tabular}{|c|c|c|c|c|c|c|}
\hline & \multicolumn{3}{|c|}{ NEW ENTRANT } & \multicolumn{3}{|c|}{ EXIT } \\
\hline & (1) & $(2)$ & (3) & (4) & $(5)$ & (6) \\
\hline PPSR & $\begin{array}{l}0.0011 * \\
(0.0006)\end{array}$ & $\begin{array}{l}0.0011 * \\
(0.0006)\end{array}$ & $\begin{array}{l}0.0011 * \\
(0.0006)\end{array}$ & $\begin{array}{c}0.000 \\
(0.001)\end{array}$ & $\begin{array}{c}0.000 \\
(0.001)\end{array}$ & $\begin{array}{c}0.000 \\
(0.001)\end{array}$ \\
\hline Employment $>=50$ & $\begin{array}{c}-0.165 * * * \\
(0.024) \\
\end{array}$ & & & $\begin{array}{c}0.094 \\
(0.120) \\
\end{array}$ & & \\
\hline $\begin{array}{l}\text { Employment }>77 \\
\quad(\text { the median size })\end{array}$ & & $\begin{array}{c}-0.181 * * \\
(0.023)\end{array}$ & & & $\begin{array}{c}0.168 \\
(0.142)\end{array}$ & \\
\hline Employment $>100$ & & & $\begin{array}{l}-0.165 \\
(0.025)\end{array}$ & & & $\begin{array}{c}0.235 \\
(0.167)\end{array}$ \\
\hline $\begin{array}{l}\text { PPSR*Big } \\
\quad \text { Employment } \geq 50\end{array}$ & & & & $\begin{array}{l}-0.002 * \\
(0.001)\end{array}$ & & \\
\hline Employment $>77$ & & & & & $\begin{array}{c}-0.003 * * \\
(0.001) \\
\end{array}$ & \\
\hline Employment $>100$ & & & & & & $\begin{array}{c}-0.004 * * \\
(0.002) \\
\end{array}$ \\
\hline Age & & & & & & \\
\hline Less than 5 years & & & & $\begin{array}{c}0.175 * * * \\
(0.032) \\
\end{array}$ & $\begin{array}{c}0.181 * * * \\
(0.032) \\
\end{array}$ & $\begin{array}{c}0.186 * * * \\
(0.032) \\
\end{array}$ \\
\hline Less than 10 years & & & & $\begin{array}{c}0.075 * * \\
(0.037)\end{array}$ & $\begin{array}{c}0.083 * * \\
(0.037)\end{array}$ & $\begin{array}{c}0.085 * * \\
(0.037)\end{array}$ \\
\hline Less than 15 years & & & & $\begin{array}{c}0.043 \\
(0.036)\end{array}$ & $\begin{array}{c}0.040 \\
(0.036)\end{array}$ & $\begin{array}{c}0.045 \\
(0.036)\end{array}$ \\
\hline Value Added & $\begin{array}{c}-0.000001 \\
(0.0000009)\end{array}$ & $\begin{array}{c}-0.000001 \\
(0.0000008)\end{array}$ & $\begin{array}{c}-0.000006 \\
(0.0000009)\end{array}$ & $\begin{array}{c}0.000 \\
(0.000)\end{array}$ & $\begin{array}{c}0.000 \\
(0.000) \\
\end{array}$ & $\begin{array}{c}0.000 \\
(0.000)\end{array}$ \\
\hline Capital Intensity & $\begin{array}{l}-0.0003 \\
(0.0004)\end{array}$ & $\begin{array}{l}-0.0002 \\
(0.0004) \\
\end{array}$ & $\begin{array}{l}-0.0003 \\
(0.0004) \\
\end{array}$ & $\begin{array}{c}0.000 \\
(0.000)\end{array}$ & $\begin{array}{c}0.000 \\
(0.000)\end{array}$ & $\begin{array}{c}0.000 \\
(0.000)\end{array}$ \\
\hline $\mathrm{N}$ & 1529 & 1529 & 1529 & 1424 & 1424 & 1424 \\
\hline Pseudo $\mathrm{R}^{2}$ & 0.047 & 0.056 & 0.047 & 0.061 & .059 & 0.059 \\
\hline
\end{tabular}

${ }^{\mathrm{a}}$ Probit coefficients (evaluated at the mean) and standard errors in parentheses.

* - Significant at $10 \%$ level; ** - significant at 5\% level; *** - significant at $1 \%$ level.

A NEW ENTRANT is a dummy variable if the plant entered the industry from 1997-2002; EXIT is a dummy variable if the plant left the industry between 1997 and 2002. PPSR is the Primary Product Specialization Ratio at the 7-digit industry level 
Table 7

The Adoption of New HRM Practices Between 1997 and 2002

(Probit Estimates) $^{\text {a }}$

\begin{tabular}{|c|c|c|c|c|}
\hline Dependent & \multicolumn{2}{|c|}{ New HRM Index ${ }^{b}$} & \multicolumn{2}{|c|}{ High New HRM Index ${ }^{c}$} \\
\hline New IT Index ${ }^{d}$ & $\begin{array}{c}0.415 * * * \\
(0.080)\end{array}$ & $\begin{array}{c}0.397 * * * \\
(0.084)\end{array}$ & & $\begin{array}{c}0.234 * * * \\
(0.060)\end{array}$ \\
\hline $\begin{array}{l}\text { High New IT } \\
\text { Index }\end{array}$ & & $\begin{array}{c}0.108 \\
(0.102)\end{array}$ & $\begin{array}{c}0.269 * * * \\
(0.096)\end{array}$ & $\begin{array}{c}0.200 * * * \\
(0.096)\end{array}$ \\
\hline $\begin{array}{l}\text { Total Plant } \\
\text { Employment }>50\end{array}$ & $\begin{array}{l}0.233 * * \\
(0.103)\end{array}$ & $\begin{array}{l}0.236 * * \\
(0.103)\end{array}$ & $\begin{array}{c}0.196 * * \\
(0.070)\end{array}$ & $\begin{array}{l}0.189 * * \\
(0.068)\end{array}$ \\
\hline $\begin{array}{l}\text { Number of } \\
\text { shopfloor } \\
\text { employees }\end{array}$ & $\begin{array}{l}-0.0009 * \\
(0.0005)\end{array}$ & $\begin{array}{c}-0.0009 * \\
(0.005)\end{array}$ & $\begin{array}{l}-0.0002 \\
(0.0004)\end{array}$ & $\begin{array}{l}-0.0002 \\
(0.0004)\end{array}$ \\
\hline Age plant & $\begin{array}{l}-0.0020 \\
(0.009)\end{array}$ & $\begin{array}{l}-0.0021 \\
(0.0019)\end{array}$ & $\begin{array}{c}-0.0044 * * \\
(0.0017)\end{array}$ & $\begin{array}{c}-0.0046^{* * * *} \\
(0.0017)\end{array}$ \\
\hline Union & $\begin{array}{c}0.132 \\
(0.102)\end{array}$ & $\begin{array}{c}0.150 \\
(0.103)\end{array}$ & $\begin{array}{c}0.105 \\
(0.099)\end{array}$ & $\begin{array}{c}0.094 \\
(0.097)\end{array}$ \\
\hline $\begin{array}{l}\text { Log likelihood } \\
\mathrm{N} \\
\text { Pseudo } \mathrm{R}^{2}\end{array}$ & $\begin{array}{c}-102.4 \\
167 \\
0.115\end{array}$ & $\begin{array}{c}-101.8 \\
167 \\
0.120\end{array}$ & $\begin{array}{c}-87.05 \\
167 \\
0.105\end{array}$ & $\begin{array}{c}-82.88 \\
165 \\
0.107\end{array}$ \\
\hline
\end{tabular}

a. Probit coefficients (evaluated at the mean) and standard errors are presented.

b. New HRM Index=1 if plant adopts one of the HR practices -- new teams, new meetings, or new training programs.

c. High New HRM Index $=1$ if plant adopts two of the three HR practices - teams, meetings, or new training.

d. New IT Index $=1$ if plant adopts one of the three new IT technologies - new CNC, FMS, or auto sensors

e. High New IT Index $=1$ if plant adopts two of the three new IT technologies - (new CNC, FMS, or auto sensors) 
Table 8

The Effects of IT on Importance of Different Types of Skills a Dependent Variable: Equals One if Skill's Importance Increased Between 1997 \& 2002

\begin{tabular}{|c|c|c|c|c|c|c|c|}
\hline & (1) & (2) & (3) & (4) & $(5)$ & (6) & (7) \\
\hline & Math & Computer & Programming & $\begin{array}{l}\text { Problem } \\
\text {-Solving }\end{array}$ & $\begin{array}{l}\text { Computer } \\
\text { and } \\
\text { Problem- } \\
\text { Solving } \\
\end{array}$ & $\begin{array}{l}\text { Cutting } \\
\text { Tools }\end{array}$ & $\begin{array}{l}\text { Multiple } \\
\text { Machines }\end{array}$ \\
\hline \multicolumn{8}{|l|}{ IT Measure for: } \\
\hline \multirow{2}{*}{$\begin{array}{l}\text { Regression 1: } \\
\text { "New IT Index," 1997-2002 }\end{array}$} & 0.128 & $0.183 * * *$ & $0.293 * * *$ & $0.138 *$ & $0.236 * * *$ & $0.246 * * *$ & 0.088 \\
\hline & $(0.087)$ & $(0.085)$ & $0.085)$ & $(0.085)$ & $(0.083)$ & $(0.084)$ & $(0.088)$ \\
\hline Pseudo- $\mathrm{R}^{2}$ & 0.024 & 0.027 & 0.071 & 0.021 & 0.039 & 0.032 & 0.022 \\
\hline \multirow{2}{*}{$\begin{array}{l}\text { Regression 2: } \\
\text { "New IT Index," 1997-2002 b }\end{array}$} & 0.096 & $0.136 *$ & $0.307 * * *$ & $0.159 *$ & $0.231 * * *$ & $0.241 * * *$ & 0.115 \\
\hline & $(0.090)$ & $(0.086)$ & $(0.087)$ & $(0.090)$ & $(0.086)$ & $(0.088)$ & $(0.092)$ \\
\hline \multirow[t]{2}{*}{ “High New IT Index,"'1997-2002 } & 0.119 & $0.160 * *$ & -0.059 & -0.072 & 0.022 & 0.021 & -0.101 \\
\hline & $(0.087)$ & $(0.072)$ & $(-0.092)$ & $(0.089)$ & $(0.091)$ & $(0.091)$ & $(-0.092)$ \\
\hline Pseudo-R $^{2}$ & 0.030 & 0.044 & 0.073 & 0.024 & 0.039 & 0.032 & 0.027 \\
\hline Sample Size & 201 & 200 & 196 & 200 & 200 & 200 & 197 \\
\hline Means & 0.57 & 0.71 & 0.53 & 0.68 & 0.50 & 0.52 & 0.59 \\
\hline \multicolumn{8}{|c|}{ Probit coefficients (evaluated at the mean) and standard errors are displayed. } \\
\hline \multicolumn{8}{|c|}{$*$ significant at $10 \% ; * *$ significant at $5 \% ; * * *$ significant at $1 \%$} \\
\hline \multicolumn{8}{|c|}{ 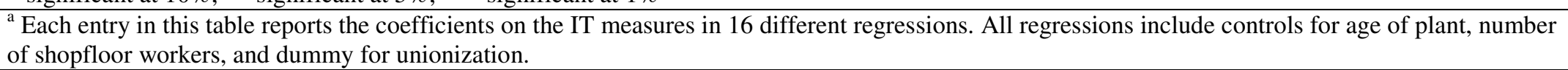 } \\
\hline
\end{tabular}


